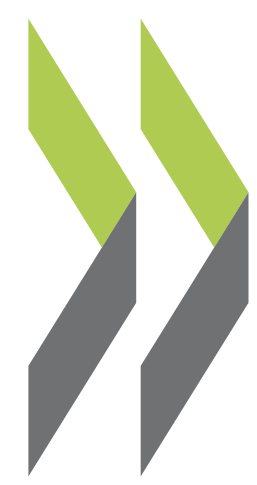

OECD Economics Department Working Papers No. 438

The Effects of EMU

on Structural Reforms

in Labour and Product

Markets
Romain Duval,

\section{Jørgen Elmeskov}


ECONOMICS DEPARTMENT

THE EFFECTS OF EMU ON STRUCTURAL REFORMS IN LABOUR AND PRODUCT MARKETS ECONOMICS DEPARTMENT WORKING PAPER, No. 438

by Romain Duval and Jørgen Elmeskov

All Economics Department Working Papers are now available through OECD's Internet Web site at http://www.oecd.org/eco/ 


\section{ABSTRACT/RÉSUMÉ}

\section{The Effects of EMU on Structural Reforms in Labour and Product Markets}

Structural reforms in labour and product markets are required in a number of euro-area countries. A question in this regard, which is the topic of this paper, is whether belonging to the euro area tends to help or hinder structural reform. The paper first reviews the theoretical arguments and the existing empirical literature - in both cases finding conclusions that point in opposite directions. Next, the paper uses an OECD database on labour market reform developed recently and an update of OECD indicators of product market regulation to compare progress in labour and product market reform over the decade since 1993 between euro-area countries and other OECD countries. Overall, euro-area countries appear to have made relatively good progress in structural reform but it is much less clear from the descriptive evidence whether progress can be ascribed to membership of Economic and Monetary Union. To explore further the role of monetary regime for structural reform, the paper undertakes an econometric examination of the likelihood that countries undertake reform in five specific areas of labour and product market policies. Based on pooled cross-country/time series Probit regressions covering 21 countries and the period 1985-2003, it is found that structural reform is strengthened by high unemployment, crisis as reflected in a large output gap, healthy public finances, reforms in other policy fields and small country size. Further, countries that pursue fixed exchange-rate regimes or participate in monetary union, and therefore have little or no monetary autonomy, appear to undertake less structural reform - with the effect possibly being concentrated on large countries.

$J E L: \mathrm{D} 7 ; \mathrm{O} 52$

Key Words: political economy; EMU; euro; reforms; labour market; product market

$* * * * * * *$

\section{Les effets de l’UEM sur la mise en œuvre des réformes structurelles sur les marchés du travail et des biens}

Des réformes structurelles sur les marchés du travail et des biens s'avèrent nécessaires dans un certain nombre de pays de la zone euro. Une question à ce propos, qui constitue le sujet de cet article, est de savoir si l'appartenance à la zone euro tend à favoriser ou à freiner la mise en oeuvre de réformes structurelles. L'article passe tout d'abord en revue les arguments théoriques et la littérature empirique - qui dans les deux cas aboutissent à des conclusions contradictoires. L'article utilise ensuite une base de données OCDE sur les réformes des marchés du travail développée récemment, ainsi qu'une actualisation des indicateurs OCDE de réglementation des marchés des biens, afin de comparer les progrès en matière de réformes des marchés du travail et des biens au cours de la décennie écoulée depuis 1993 entre les pays de la zone euro et les autres pays de l'OCDE. Dans l'ensemble, il apparaît que les pays de la zone euro ont relativement bien progressé en matière de réformes structurelles, mais il est beaucoup moins évident au vu de l'analyse descriptive que ces progrès peuvent être attribués à l'appartenance à l'Union Économique et Monétaire. Afin d'explorer plus avant le rôle du régime monétaire dans la mise en œuvre de réformes structurelles, l'article effectue une analyse économétrique de la probabilité que les pays entreprennent des réformes dans cinq types de politiques relatives aux marchés du travail et des biens. Sur la base de régressions de type Probit sur données de panel couvrant 21 pays au cours de la période 1985-2003, il ressort que la mise en œuvre de réformes structurelles est renforcée par un chômage élevé, une crise économique telle que mesurée par un écart de production élevé, une situation saine des finances publiques, l'existence de réformes dans d'autres domaines et la faible taille du pays considéré. En outre, les pays participant à un régime de changes fixes ou à une union monétaire, et qui par conséquent disposent d'une autonomie limitée voire inexistante de leur politique monétaire, apparaissent entreprendre moins de réformes structurelles - cet effet étant potentiellement plus marqué dans le cas des grands pays.

$J E L:$ D 7 ; O52

Mots clés : économie politique ; UEM ; euro ; réformes ; marché du travail ; marché des biens

Copyright OECD 2005

Applications for permission to reproduce or translate all, or part of, this material should be made to: Head of Publications Service, OECD, 2 rue André-Pascal, 75775 Paris Cedex 16, France. 


\section{TABLE OF CONTENTS}

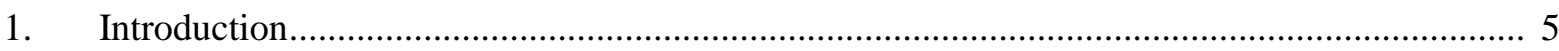

2. Arguments linking structural reform intensity to EMU ........................................................ 9

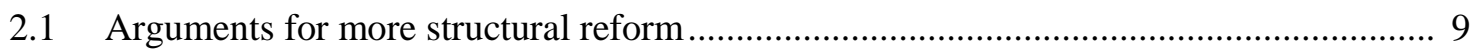

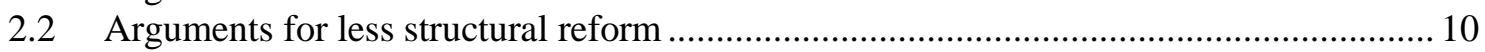

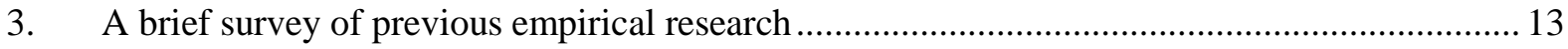

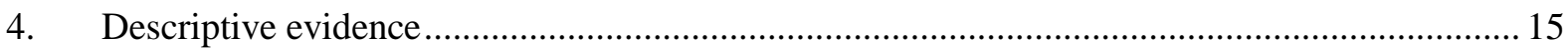

4.1 Labour market reforms over the period 1994-2004 …................................................. 15

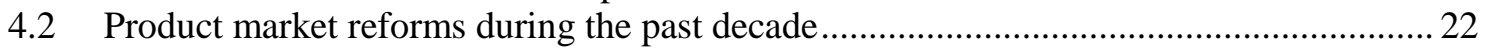

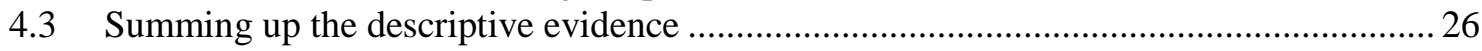

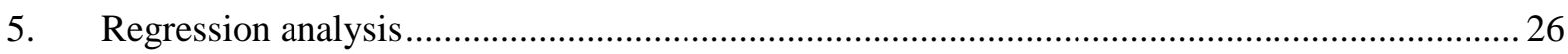

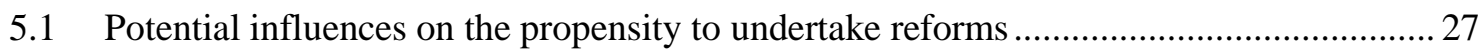

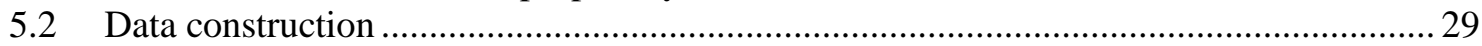

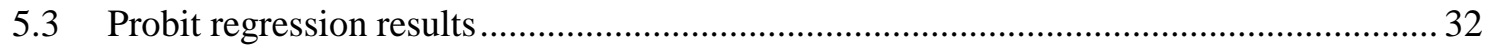

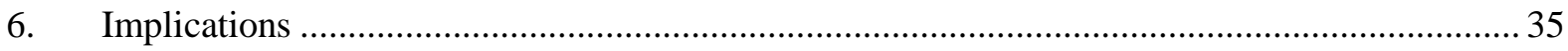

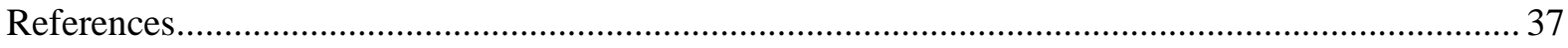

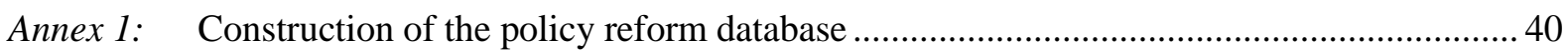

Box 1. The effect of a drop in the NAIRU under different assumptions........................................ 11

\section{Figures}

1. Unemployment and participation rates across OECD countries, 2004 …........................... 6

2. Strength of anti-competitive product market regulation, 1998 and 2003 ............................. 7

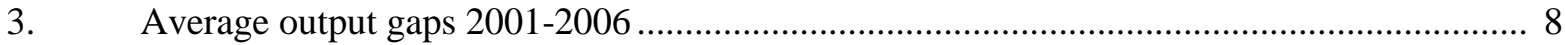

4. Intensity and timing of recent labour market reforms in OECD countries ............................ 17

5. Intensity of labour market reforms in OECD countries, 1994-2004 ..................................... 18

6. Intensity of labour market reforms in specific areas, 1994-2004 .......................................... 20

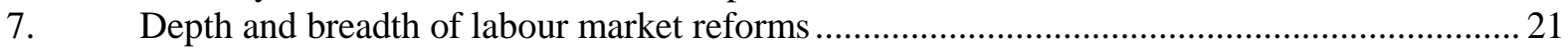

8. Initial conditions and intensity of labour market reforms ................................................... 23

9. Intensity of labour market reforms in big and small EMU countries, 1994-2004 .................. 24 


\section{ECO/WKP(2005)25}

10. Evolution of the OECD indicator of product market regulation in nonmanufacturing industries, 1994-2003 ...

11. Changes in product market regulation over 1993-1998 and intensity of labour market reforms over 1999-2000.

12. Share of countries where at least one major reform has been implemented over 1985-2003

\section{Tables}

1. Aggregate reform intensity indicator, reform intensity indicators by area: $1994-2004 \ldots \ldots . . .19$

2. Probit estimates of the determinants of structural reforms over 1985-2003: pooled data ...... 32

3. Probit estimates of the determinants of structural reforms over 1985-2003:

stacked up data..... 
ECO/WKP(2005)25

\title{
THE EFFECTS OF EMU ON STRUCTURAL REFORMS IN LABOUR AND PRODUCT MARKETS
}

\author{
by \\ Romain Duval and Jørgen Elmeskov ${ }^{1}$
}

\section{Introduction}

Many European countries, and in particular a number of those that belong to the euro area, are usually seen as being in need of structural reform. The symptoms include high unemployment and low labour-force participation (Figure 1). Contrary to some assertions, low employment in many euro-area countries is not predominantly the result of an idiosyncratic European taste for leisure but to a large extent reflects distortions created by policies and institutions. ${ }^{2}$ Weak employment also strains government budgets which, in a context of population ageing, is not only undesirable but also may become unsustainable.

In many euro-area countries, low employment is accompanied by sub-par productivity levels. ${ }^{3}$ There are many causes for weak productivity but barriers to competition, reallocation and innovation created by structural policies in product, labour and financial markets are certainly among them. Indeed, in

1. Respectively, Economist and Deputy-Director in the Policy Studies Branch of the OECD Economics Department. Franck Sédillot undertook the model simulations behind Box 1 and Jackie Gardel, Lyn Urmston and Martine Levasseur provided secretarial and statistical assistance. Helpful comments were provided by Jean-Marc Burniaux, Pietro Catte, Michael P. Feiner, Peter Hoeller, Vincent Koen, Anabelle Mourougane, Giuseppe Nicoletti, Flavio Padrini, Bent Sorensen and William Tompson. Nonetheless, the responsibility for all remaining mistakes lies with the authors. The views and results presented in this paper are those of the authors and do not necessarily reflect those of the OECD or its Member countries. The paper was initially prepared for the conference on "What Effects is EMU Having on the Euro Area and its Member Countries?" organised by the European Central Bank and held in Frankfurt on 16-17 June 2005.

2. About half of the difference between the number of hours worked per capita in the United States and the "old" members of the European Union reflects lower participation rates and higher unemployment in Europe and these differences can to a large extent be explained by different policy settings (e.g. Duval, 2004; Jaumotte, 2004; and Elmeskov et al., 1998). Moreover, part of the gap in the number of hours worked per employed may also reflect policy distortions (Prescott (2004) highlighted the effect of taxes which may affect labour supply along both the intensive and the extensive margin) even though market failure (e.g. asymmetric information, inter-personal complementarities in leisure consumption) could boost US hours beyond the social optimum (Landers et al., 1996 and Alesina et al., 2005).

3. Observed hourly productivity in countries like Belgium and France is as high as or even higher than in the United States but, to a large extent, this reflects the exclusion of low-productive workers from the labour force (Bourles and Cette, 2005). 
spite of progress over past decades, euro-area countries remain more afflicted by anti-competitive regulatory barriers than most English-speaking countries (Figure 2). This again underlines the need for structural policy reform.

Figure 1. Unemployment and participation rates across OECD countries, 2004

\section{A. Unemployment rates}

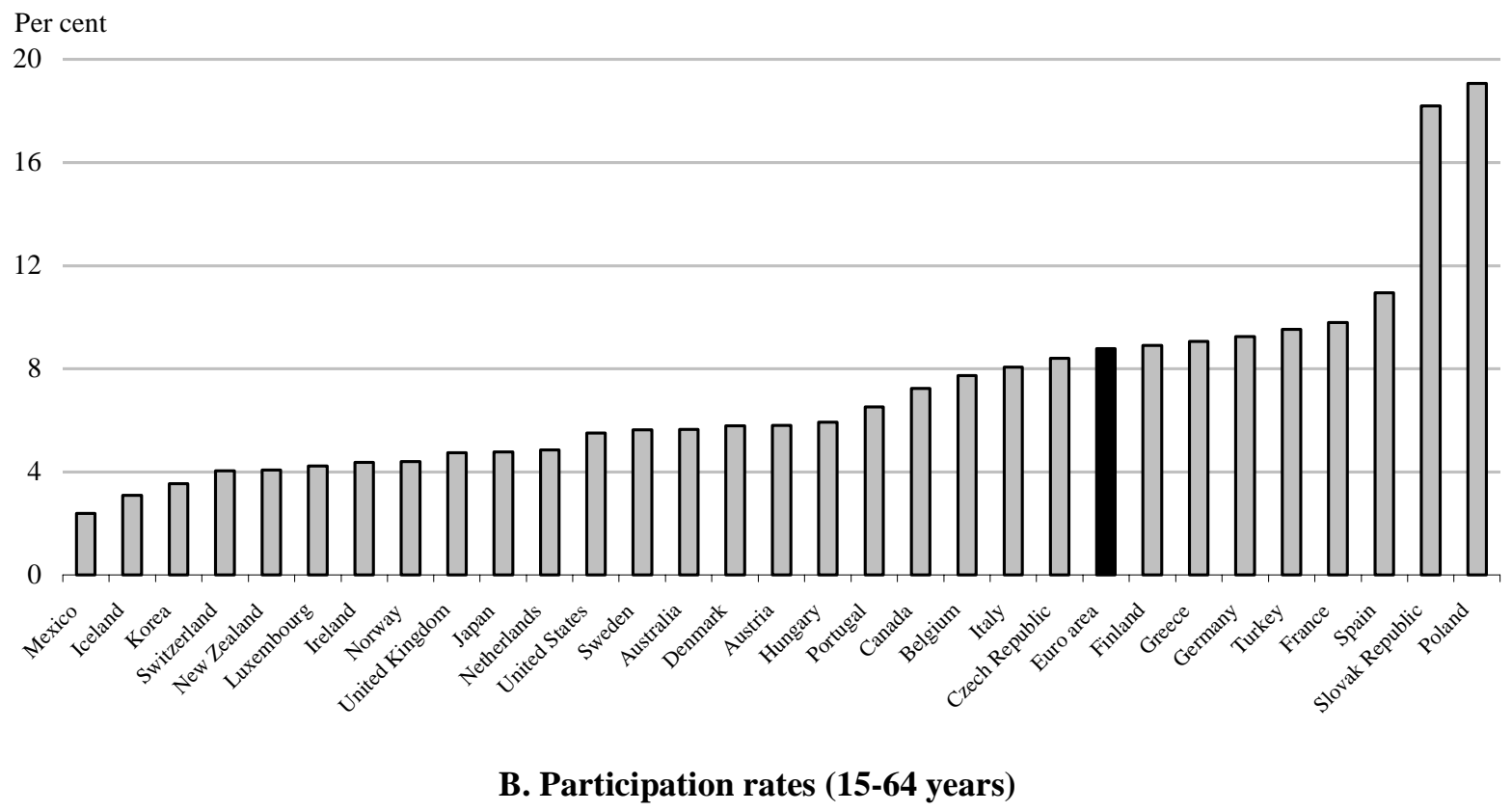

Per cent

100

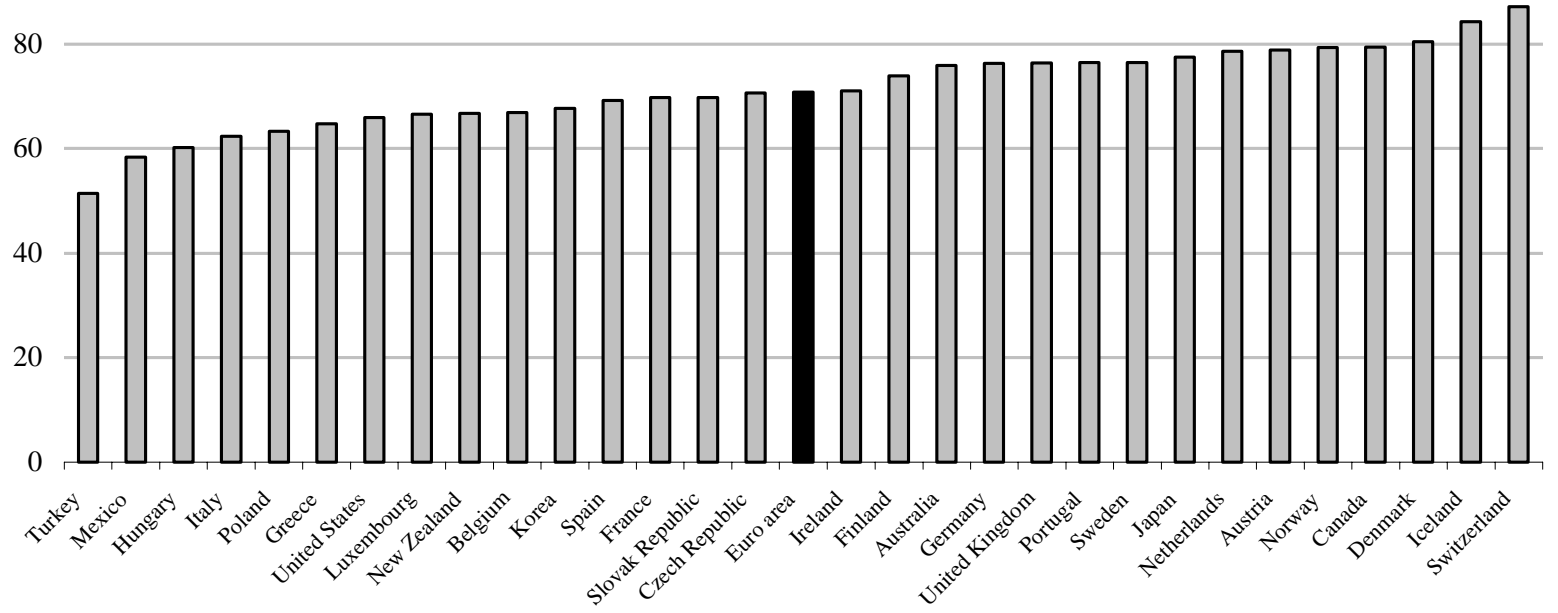

Source : OECD. 
Figure 2. Strength of anti-competitive product market regulation, 1998 and 2003

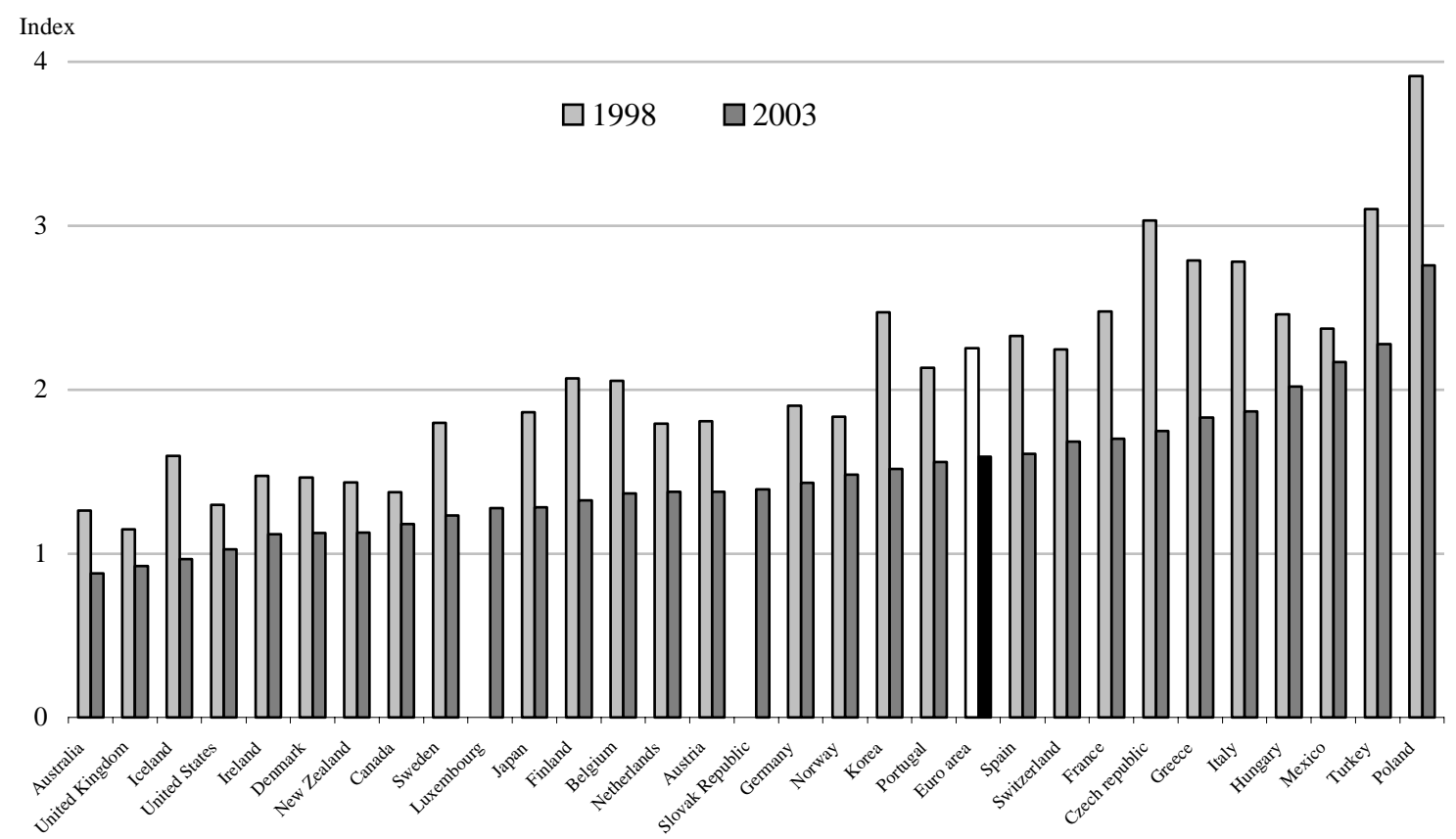

Note : The indicator of regulation is measured on a scale from 0 (most liberal) to 6 (most restrictive) and is described in Conway et al. (2005).

Source: OECD.

Recent episodes of conjunctural weakness in the euro area also point to a need for structural reform. Indeed, the euro area has exhibited less resilience than a number of non-euro-area countries in the face of a series of common shocks, which since the turn of the century have included the bursting of the IT bubble, corporate governance scandals, terrorist attacks and higher oil prices. It is obviously difficult to standardise across countries but, nonetheless, it is hard to argue that differences in exposure to shocks or in macroeconomic policy stances between, on the one hand, the euro area and, on the other hand, Australia, Canada, New Zealand and the United Kingdom can account for the divergence in output gaps across the two country groups (Figure 3). These differences in resilience - which are also visible inside the euro area probably reflect both different capacities to adjust to shocks and different responses to changes in monetary policy - i.e. differences in the strength of the monetary policy transmission mechanism. ${ }^{4}$ Again, such differences are likely to reflect structural policy settings. ${ }^{5}$

4. Recent work suggests that the monetary policy transmission mechanism in the euro area relies more heavily on effects via business investment whereas in the United States effects via private consumption also contribute importantly (e.g. Angeloni et al., 2003).

5. Catte et al. (2004) emphasise the role of structural policies affecting housing and mortgage markets in this regard. 
Figure 3. Average output gaps 2001-2006

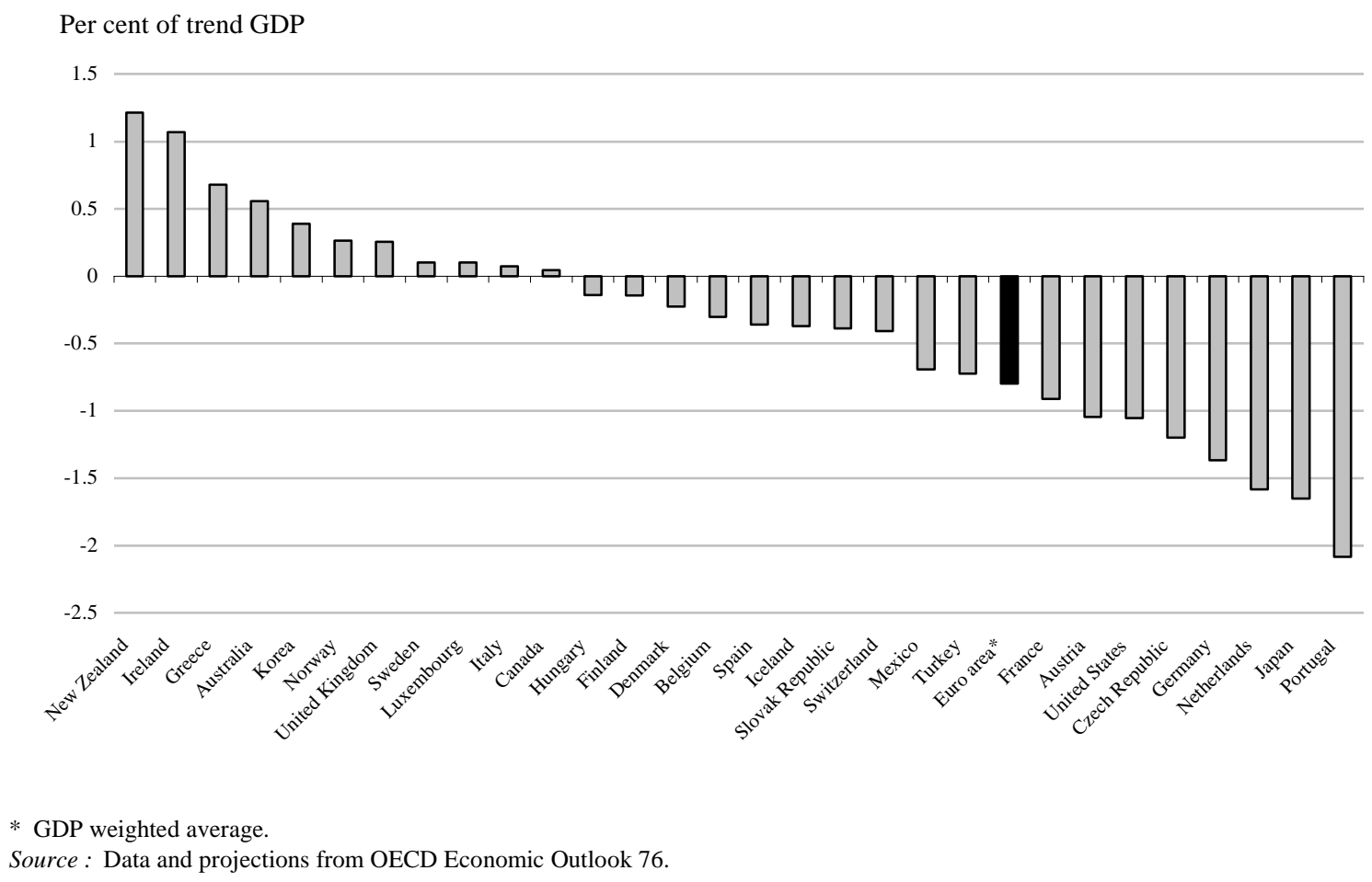

It could of course be argued that current structural policy settings reflect a collective policy choice and that the associated weaknesses in terms of employment, productivity and resilience are just the price to be paid for this choice. This argument is often presented with reference to a particular European "social model". In practice, however, there is no such thing as a single European model. Indeed, some smaller European countries combine structural policy settings that result in much better than average macroeconomic outcomes with social outcomes that are as good as or better than in the larger euro-area economies. ${ }^{6}$ Hence, the argument that weak macroeconomic performance is the price to pay for better social outcomes does not ring true.

That said, structural reforms cannot generally be assumed to be Pareto improving. If they were, they would presumably be politically easy to undertake. Rather, structural reforms usually involve a reduction in rents and those who see their rent reduced can hardly be expected to be in favour. The argument in favour of structural reform thus rests on a weighing of the losses for those who see their rents reduced against the gains for others. It is a well-known feature of the political economy of structural reform that those who see their rent reduced tend to be easy to identify, to be exposed to a significant loss, to feel the pain up-front and to be well organised (e.g. Olson, 1965). By contrast, the gains from reform accrue to no clearly identifiable group, are usually widely dispersed with limited benefit for each individual and often occur with a considerable delay. As a general observation, opportunity cost is not a concept that plays well in politics.

6. This is the case whether hard indicators, such as poverty rates, or soft indicators, such as surveys of happiness, are considered (OECD, 2005a). 
As a result of those features, structural reform is usually an uphill battle. This paper will not address the overall incentives and disincentives to undertake structural reform. Rather, and more modestly, it deals with the marginal impact of EMU on the political economy of structural reform in product and, in particular, labour markets. In this regard, two caveats are in order.

First, putting the main focus on labour markets is justified by some of the main obstacles to euro-area growth, employment and fiscal sustainability being related to labour-market policies. ${ }^{7}$ At a more mundane level, and relevant for the empirical part of the paper, more information is available for a wider range of policies over a longer period as concerns labour markets than is the case for most policies directly affecting product and financial markets. However, the focus on labour markets should not be taken to imply that reforms in other markets are unimportant.

Second, despite the emphasis on the role of EMU, general arguments concerning the political economy of structural reform such as those advanced above are likely to remain more important than any marginal influence of EMU in terms of either facilitating or hindering structural reform.

The paper proceeds by reviewing in Section 2 some of the arguments that have been advanced in the literature as to why EMU may affect the political economy of structural reform. Section 3 then reviews the scarce empirical evidence presented in the literature while Section 4 presents our own attempt to look at some descriptive evidence on labour-market reform in euro-area and non-euro-area economies. Section 5 proceeds to an econometric investigation of the impact that monetary policy autonomy may have on the propensity to undertake labour-market reform. Finally, Section 6 sums up the evidence and discusses some possible policy implications.

\section{Arguments linking structural reform intensity to EMU}

There are arguments for EMU both strengthening and weakening structural reform. Many of them revolve around the tension between most structural policy settings being decided at the national level while EMU meant transferring monetary policy competency to the euro-area level (and, in view of the Stability and Growth Pact (SGP), also giving up a modicum of autonomy over fiscal policy).

\subsection{Arguments for more structural reform}

On the side of EMU strengthening incentives for structural reform, the most prominent argument has been TINA - There Is No Alternative. ${ }^{8}$ The argument is that in a monetary union, monetary policy (including nominal exchange-rate adjustment) is no longer available to individual countries to respond to an asymmetric shock. Hence, incentives should become stronger to undertake structural reform so as to facilitate a market-based adjustment to such shocks. ${ }^{9}$ In the absence of substantial migration flows - an important aspect of adjustment to asymmetric shocks in the United States but a remote prospect in the euro area - such reforms would have to strengthen wage and price responsiveness to changes in demand and supply. As an addition to the TINA argument, restrictions on fiscal policy in EU countries may constrain

7. OECD (2005b) uses a consistent procedure to derive policy priorities to enhance economic growth across OECD countries and identifies labour market reforms as being particularly important in euro-area countries.

8. A number of authors have made this point including Bean (1998).

9. Incentives may also become stronger for wage-setters to shorten contract periods thereby allowing greater wage flexibility in the face of asymmetric shocks (though a more credible low inflation environment may tend to lengthen contract periods and, in any case, the shortening effect may be limited according to Calmfors, 2001b). Such endogenous responses by private agents lie outside the scope of this paper (but could, in principle, weaken the TINA argument for more structural reform as a result of EMU). 
the use of this instrument for stabilisation purposes unless countries start out from a position of fiscal strength. However, this latter argument may have become less valid following recent discussion and re-interpretation of the SGP.

A further variant on and amplification of the TINA argument is based on the notion that EMU might increase the incidence or strength of asymmetric shocks. Such a tendency would arise from lower trading costs under EMU leading to increased specialisation along geographical lines. In practice, however, evidence suggests that trade integration effects may dominate, leading to greater dispersion rather than concentration of shocks (OECD, 2004). ${ }^{10}$

Further arguments why EMU may stimulate structural reform include the greater transparency created by the single currency, which may expose more clearly the costs of structural rigidities as reflected in relative prices. As well, reduced costs of trading and greater transparency should increase product-market competition, thereby reducing the size of product market rents in EMU countries. ${ }^{11}$ With less rent to be captured, the resistance to reforms of structural policies that enable such capture may become smaller.

It has also been argued that increased mobility of capital - because the common currency lowers the costs of capital mobility both directly and indirectly, as it reduces the costs of trade in goods and services - could strengthen tendencies for countries to engage in a game of competitive structural reform so as to attract capital inflows. ${ }^{12,13}$

\subsection{Arguments for less structural reform}

There are also a number of arguments as to why EMU may weaken the process of structural reform. Perhaps the most prominent argument is that the up-front costs of structural reform may be larger with a common currency (and some degree of restriction on the use of fiscal policy). ${ }^{14}$ The idea is that

10. Greater integration of product markets might also be seen as reducing the effective centralisation of wage bargaining. For countries currently near the top of the "Calmfors-Driffill hump" this could be directly beneficial but for countries with high centralisation at the outset that would not be so. In the latter, incentives for reforms that would shift bargaining further towards decentralization could then increase as a result of EMU (Bean, 1998). On the other hand, Calmfors (2001b) argues that EMU, at least for a while, could lead to increased attempts at national co-ordination of wage bargaining in order to increase nominal wage flexibility as a substitute for lost monetary policy autonomy.

11. Based on evidence concerning (limited) price structure convergence among core-EMS countries as compared with other countries, Haffner et al. (2000) play down the likely impact of EMU on product market competition.

12. To the extent that investment flows are attracted by the opportunity of monopoly rents, countries could in principle try to attract such flows by offsetting the increased competition resulting from the common currency by increasing other barriers to competition. In practice, evidence on the determinants of foreign direct investment (FDI) across OECD countries indicates that tariffs may induce some "tariff-jumping" FDI in the manufacturing sector but that domestic product market regulation, which is what is relevant in the context of EU competency as regards tariffs, exerts a significant negative effect on inward FDI supporting the argument that competition to attract FDI will increase pressure to liberalise (Nicoletti et al., 2003).

13. Such competitive structural reform could in return increase pressure for the imposition of supra-national "minimum standards" for structural policies, possibly shifting the quest for both rent-seeking and structural reform to the level of the euro area.

14. A number of authors have emphasized this point including OECD (1997) and Bean (1998). Saint-Paul and Bentolila (2000) modify the argument to concern in particular "major" structural reforms, arguing that the optimal size of reform is smaller under EMU. If, as suggested by Elmeskov et al. (1998) and Orszag and 
structural reform expands potential output but is not necessarily accompanied by a corresponding expansion in aggregate demand. In a single country with an independent monetary policy, lower interest rates and exchange rate depreciation could in principle boost demand and thereby allow the added supply capacity to be "crowded in". But in a monetary union, the main mechanism for crowding in added supply is a lower real exchange rate brought about by an extended period of slack and associated weak inflation. Given the nature of this mechanism, the up-front costs of structural reform may rise more as a result of moving to EMU in large, relative closed economies than in smaller, more open economies. Simulations using OECD's macroeconomic model, Interlink, supports these conjectures (see Box 1).

\section{Box 1. The effect of a drop in the NAIRU under different assumptions}

The role of country size and monetary policy regime for the transition costs of structural reform can be illustrated using the OECD's Interlink model. ${ }^{1}$ Concretely, a hypothesised fall in the NAIRU by 1 percentage point is simulated on the country models for France and the Netherlands. In both cases, nominal interest rates and fiscal policy are assumed to remain unchanged. However, the French country model is also simulated under the assumption that nominal short-term interest rates are adjusted so as to stabilise inflation.

The demand side of the Interlink model embodies a traditional Keynesian structure, with no forward-looking behaviour of consumers and producers. Under these conditions, and with unchanged nominal interest rates, the drop in the NAIRU will set in motion a fall in inflation and the real exchange rate, thereby on the one hand boosting competitiveness but also raising real interest rates.

In the more open Dutch economy, improved competitiveness leads to market share gains that fairly quickly translate into a fall in unemployment towards the new lower NAIRU (see figure). In the more closed French economy the process is much slower (Case 1). However, in the scenario where interest rates are lowered (with no impact on the exchange rate assumed) the adjustment in the French economy is speeded up significantly (Case 2).

1. Simulation exercises with a similar flavour are presented in OECD (1997) and Bean (1998).

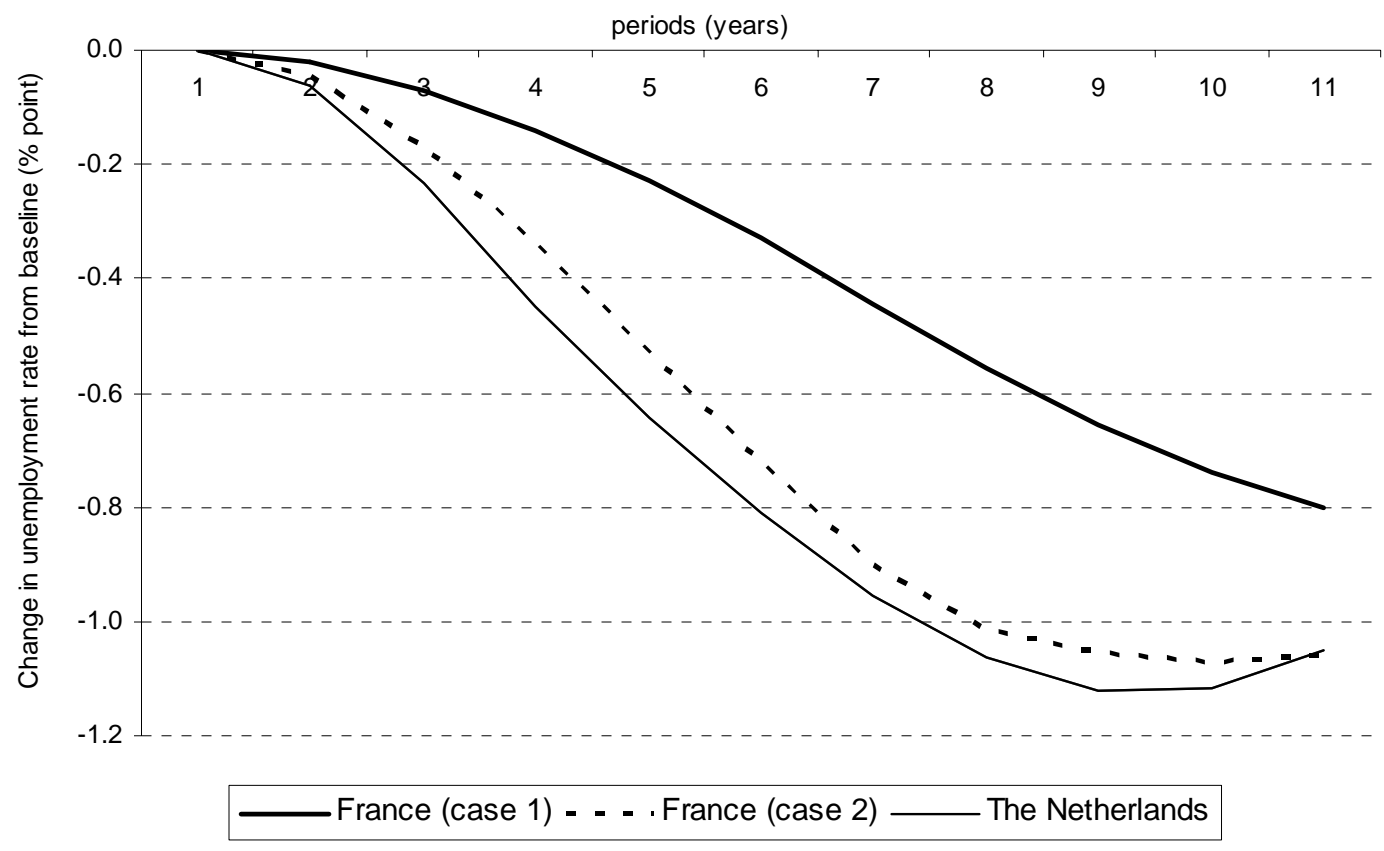

Snower (1998), there are political or economic complementarities across individual reforms, a tendency for the optimal overall reform size to decline under EMU could be problematic. 
The crowding-in argument needs to be qualified in a number of ways, however. First, its basic premise - that demand does not spontaneously expand in response to added supply as a result of structural reform - may be inaccurate. In principle, rational and forward-looking households and firms should respond up-front to the increase in, respectively, permanent income and output. The extent to which this would happen in practice might depend on features of financial markets - in particular the extent to which households enjoy wealth gains from higher share prices and firms are able to secure financing on the basis of future production possibilities rather than pre-existing collateral. In general, such spontaneous demand effects are likely to be weaker in euro-area countries than in the United States. Indeed, the US experience in the 1990s was one of higher productivity growth (driven by information and communication technology) that found its way quickly into demand - to the point of demand effects outstripping supply effects in the short run.

It is also the case that the balance between supply and demand effects of structural reform is likely to depend on the nature of the structural reforms. Experience from many countries suggests that structural reforms that remove restrictions in financial markets may well stimulate demand more than supply in the short run. By contrast, it might be thought that reforms in labour markets are susceptible to weaken demand in the short run to the extent they may be associated with reduced public transfers and increased precautionary saving. This is evidently of particular concern since euro-area reform needs are concentrated in labour markets. ${ }^{15}$

In any case, it is very difficult to predict ex ante the effects of particular structural reforms on potential and actual output as well as inflation. Hence, in the real world - as opposed to model scenarios an autonomous monetary policy would probably be confined to reacting to inflation developments as they unfold rather than anticipating the precise impact of reform. In consequence, monetary policy could provide only partial accommodation to structural reform - even if some "testing of the waters" might be considered. ${ }^{16}$

In principle, fiscal policy could help crowd in resources in the wake of structural reform. This is particularly so in the case of reforms that change an economy's structural rate of employment since such reforms would improve the cyclically-adjusted budget balance corresponding to a given actual budget balance and employment rate. ${ }^{17}$ Put differently, not changing the actual budget balance post-reform and before employment has had time to adjust would imply an effective tightening of fiscal policy. That said, empirical evidence suggests that private saving behaviour to a large extent offsets changes in fiscal policy. ${ }^{18}$ In any case, the SGP might be seen to constrain the use of fiscal policy to accommodate structural reform even though the recent reorientation of the SGP should in principle have made such accommodation easier (accommodation has of course been perfectly feasible all along for countries that undertook reform from a position of close to budget balance or surplus).

15. Empirical evidence on the current-account effects of structural reform seems to corroborate these differences across types of structural reform (Kennedy and Sløk, 2005).

16. For further discussion, see Bean (1998).

17. Reforms differ in their impact on budgets. Reforms that boost productivity without raising equilibrium employment will have only limited impacts on the cyclically-adjusted budget balance unless transfer recipients and public sector employees do not share fully in the real income gains created by higher productivity.

18. Pooled cross-country time-series estimation across OECD countries suggests that the private saving offset to changes in cyclically-adjusted budget balances could be about half in the first year, rising to some $70 \%$ in the long run (OECD, 2004b). Tests suggest that the only significant exception to this pattern is to be found outside the euro area (the United States). 
A further argument for structural reform incentives being weaker in a monetary union focuses more on the long-term effects of reform. It posits that, in general, structural rigidities tend to create an inflation bias as policymakers try to push unemployment down below its equilibrium level. Hence, one of the gains from structural reform for a single country with an independent monetary policy is a reduced inflation bias in monetary policy. By contrast, structural reform in any individual country inside a monetary union is unlikely to affect union-wide inflation bias and the country's incentive for reform is therefore smaller than with an autonomous monetary policy (e.g. Calmfors, 2001a). In practice, with most central banks being independent and focused on anchoring inflation expectations on more or less explicit inflation targets, this argument may be thought to be of lesser relevance.

A final argument for less structural reform under EMU relates to risk premia in long-term interest rates. With monetary autonomy, structural reform that makes an economy more resilient to shocks (via more rapid market adjustment and more effective monetary policy transmission) should reduce output volatility and the need for large swings in policy interest rates and exchange rates. In turn, this should be reflected in lower risk premia. Greater resilience to shocks should also limit swings in budget balances and reduce the risk that a large negative shock may lead to an unsustainable fiscal position, which again could be reflected in lower risk premia. In EMU, there is no individual country currency premium that can be reduced as a result of structural reform. In principle, default risk premia could be reduced but these seem in practice to be virtually non-existent. Hence, the gain from structural reform in terms of lowering risk premia is lower under EMU.

\section{A brief survey of previous empirical research}

EMU is too recent a phenomenon to readily allow full-fledged econometric analysis of its impact on the propensity to undertake structural reform. Empirical inference is further complicated by EMU being preceded by a period of qualification during which incentives for structural reform may have resembled neither those existing under EMU nor those existing in the absence of EMU. In consequence, empirical analysis on the effects of EMU is scarce and tends to be fairly descriptive and ad hoc.

Relying on a descriptive approach, van Poeck and Borghijs (2001) argue that the prospect of qualifying for EMU should provide as big an incentive for labour-market reform as EMU membership itself. Hence, they consider the progress EMU and non-EMU countries made over the 1990s in implementing the priorities for labour-market reform established by the OECD in the context of its Jobs Strategy. ${ }^{19}$ The authors find that the average follow-through rate is the same in EMU and non-EMU countries. This should, however, be seen in the context of EMU countries having higher unemployment than non-EMU countries and therefore being in greater need of reform. Indeed, across non-EMU countries there is a positive correlation between the follow-through rate and initial unemployment, while such a relationship is absent for EMU countries. The authors conclude that EMU countries did not reform more than other countries and, unlike elsewhere, their progress on reform seemed unrelated to the initial level of unemployment. ${ }^{20}$

Also in the descriptive category of research, and covering a period stretching up to 1999, Bertola and Boeri (2001) reach opposite conclusions. The authors consider only reforms to cash transfers to people of working age (including unemployment benefits) and to job protection, and they distinguish between radical and marginal reforms. Calculating and comparing the average number of reforms per country inside and outside the euro area, the paper interprets the findings as showing that reforms accelerated more in the

19. The areas covered are wage formation, unemployment benefits, tax wedges, active labour market policies, job protection and working time arrangements.

20. The authors pursue the same type of analysis using a completely different measure of progress in labour market reform and reach essentially the same conclusions. 
euro area than outside since the early 1990s. ${ }^{21}$ In this regard, it is difficult to disentangle expectational effects of impending EMU from other drivers but the authors argue that the observed post-1997 spurt in reform is stronger in euro area countries than outside and can more safely be related to EMU. At the same time, however, it is found that the ratio of marginal to radical reforms has increased since 1997.

Based on calibrating a dynamic, theoretical model with parameters corresponding to different archetypes of economies, reforms and policymakers, Saint-Paul and Bentolila (2000) suggest that the impact of EMU on reform incentives varies across different situations. More specifically, the incentives to undertake reforms which speed up adjustment to country-specific shocks but do not alter the economy's long-term equilibrium (i.e. reforms that do not require the crowding-in of an effective increase in resources) could in some cases increase as a result of EMU. Whether in practice it is possible to identify reforms that affect only the dynamic response to a shock but not the steady state is another matter. As concerns reforms which alter the economy's steady state, i.e. increase long-run employment, the paper argues that the disincentives arising because the up-front crowding-in is slower under EMU typically outweigh the positive incentives from dealing more effectively with country-specific shocks. ${ }^{22}$ Nonetheless, for small reforms there could be (rare) circumstances where loss of monetary autonomy might conceivably increase the incentives for reform. ${ }^{23}$

As a rare example of econometric research, IMF (2004) attempts to explain the policy stance in a large number of structural policy areas across many OECD countries between the mid-1970s and the late 1990s. The study explores the impact of a range of factors including macroeconomic conditions, political institutions, reform design and variables aimed to capture attitudes towards structural reform. Among the macroeconomic conditions, the study finds that fiscal surpluses tend to favour reform in product and labour markets but it does not consider the influence of monetary policy. It also finds that EU membership is associated with faster moves towards liberalisation of product markets. Whether this represents an effect of EMU and/or policies to prepare for EMU is unclear, however. The internal market programme and the starting point in terms of over-regulated product markets are competing explanations for this finding. As concerns labour-market reform, the findings of the study are somewhat ambiguous, with EU membership (weakly) associated with greater reform in some specifications but (more significantly) associated with less reform in other specifications. The indicator of tax reform considered in the study is closely associated with improved labour-market incentives and is always strongly negatively correlated with EU membership. At a more general level, the study finds positive spillovers between structural reforms in different areas in the sense that progress in a given policy area is positively affected by reforms in other policy areas.

21. The conflicting findings as between van Poeck and Borghijs (2001) and Bertola and Boeri (2001) may reflect the difference in the coverage of reforms. Haffner et al. (2000) report evidence that core-EMS countries implemented more reforms over the period 1986-97 than other countries but made less progress in terms of following through on OECD recommendations.

22. The paper assumes no direct demand effects from undertaking reform.

23. The argument relies on monetary policy outside EMU following a pre-set response pattern to economic shocks and this pattern becoming sub-optimal post-reform, implying that the non-response under EMU may be less costly than following the pre-set response pattern outside EMU. By ignoring the possibility for the monetary policy response pattern to be altered as a result of structural reform outside EMU, the argument seems in reality to stack the cards very heavily in favour of EMU in some specific circumstances having a positive incentive effect on minor reforms. More convincingly, the paper argues that for major reforms the crowding-in under EMU could imply a spell of deflation which might be seen as particularly unattractive. 


\section{Descriptive evidence ${ }^{24}$}

This section uses OECD indicators to shed light on the question of whether EMU has affected the process of structural reform. In particular, the descriptive evidence is used to look for possible associations between EMU membership and the intensity, timing and design of labour and - to a lesser extent - product market reforms.

\subsection{Labour market reforms over the period 1994-2004}

\section{Overall intensity and timing of reforms}

As part of the ongoing reassessment of its recommendations to address issues of high unemployment and low labour-force participation, the OECD has recently carried out a thorough assessment of recent labour market reforms (Brandt, Burniaux and Duval, 2005), on which this section relies heavily. All policy measures implemented by OECD member countries over the period 1994-2004 have been evaluated for 44 possible individual categories falling under seven broad policy areas: ${ }^{25}$

- $\quad$ active labour market policies (ALMPs)

- taxes and social security contributions

- employment protection legislation (EPL)

- unemployment benefit systems

- wage formation and industrial relations

- working-time flexibility and part-time work

- old-age pension systems and early retirement schemes

In each of the 44 individual policy categories, scores are assigned to reforms for every OECD country and each of the two sub-periods $1994-98$ and 1999-2004. ${ }^{26}$ They can be either positive or negative, depending on whether the measure considered is in line or at odds with the general thrust of OECD policy recommendations, as summed up in OECD (1999). The results are then aggregated up to the seven broader policy areas above.

Whenever possible, the scoring method at the level of individual policy categories relies on quantitative indicators, with the score of an individual policy measure depending on the associated change in the relevant indicator. For example, changes in the OECD summary measure of unemployment benefits are used to assign a score in the sub-category "benefit replacement rates" of the broader area "unemployment benefit systems". However, in certain cases, sources of information are qualitative and their interpretation is more subjective (e.g. some aspects of ALMPs). More broadly, some degree of

24. In this, as well as the following, section, EU refers to the 15 members before the recent expansion of membership.

25. For full details, see Brandt, Burniaux and Duval (2005).

26. The scores assigned for the period 1999-2004 incorporate all legislated reforms up to mid-2004, even though some of these may not yet have been fully implemented (e.g. some aspects of the Agenda 2010 in Germany, or various pension reforms that are phased in very gradually). 
uncertainty and judgement is inherent to any effort to quantify individual reforms and, perhaps even more so, to aggregate such quantifications across different policy instruments. ${ }^{27}$

Bearing these caveats in mind, illustrative indicators of reform intensity within each of the seven policy areas can be calculated as the ratio of the actual to the maximum possible score, where the latter is the score which would be obtained if maximum scores had been reached at the level of all individual policy categories belonging to the relevant policy area. In addition, an illustrative indicator of the overall intensity of reforms is calculated as the ratio of the total actual score across the seven broad policy areas to the maximum possible score. ${ }^{28}$

Aggregate results for the entire period 1994-2004 are presented in Figure 4 (Panel A). On average, the propensity to carry out labour market reforms has been greater in EU than in other OECD countries, with six EU countries in the top six positions. Still, this progress has to be seen in light of the need for reform, as discussed below. Within the EU, the overall reform intensity appears to have been marginally lower among EMU members than in others (Denmark, Sweden, United Kingdom). Not too much should be made of this finding, however, since the non-EMU EU group consists of only three countries, among which the top reformer (Denmark) has its currency tied to the euro (through the new exchange-rate mechanism, ERMII). In contrast with the findings of Bertola and Boeri (2001), the advent of EMU did not seem to coincide with an acceleration of reforms, as shown by the lower average reform intensity in EMU countries over 1999-2004 compared with 1994-98 (Figure 4, Panel B). This may to some extent reflect the limited political capital some governments were left with after a painful period of fiscal adjustment in the run-up to EMU. In any case, no such slowdown was observed in non-EMU EU and it was less pronounced in other OECD countries. Nevertheless, one can not rule out that the fairly high reform intensity observed in EMU countries during the period 1994-98 was itself fostered by expectational effects of EMU. The time span covered here is unfortunately too short to explore this possibility.

\section{Disaggregated analysis by policy area}

Labour market reforms implemented during the last ten years have been deeper in certain policy areas than in others, but signs of systematic divergences in reform "profile" between EMU countries and other countries are not very strong (Figure 5). Many countries have improved the effectiveness of their ALMPs, including through greater emphasis on activation, increased monitoring of work availability, enhanced placement efforts and more efficient administration of their public employment services (see Table 1 for detailed country scores in each policy field). Likewise, efforts have often been made to reduce labour tax wedges. In both fields, as well as concerning reforms to enhance working-time flexibility, action taken in euro-area countries has gone farther than in non-EU countries, albeit not as far as in non-EMU EU countries in the case of ALMPs.

Reforms have been much more modest in the areas of EPL and employment benefits where political resistance is likely to be greater, pointing to the role played by political economy considerations in shaping recent reform patterns. In both areas, reform intensity in EMU countries is broadly in line with the OECD average.

27. Problems include: $i$ ) the degree to which a given reform is actually enforced may differ widely across countries; ii) no account is made for the possibility of non-linear policy effects (i.e. the possibility that a given reform may have different impact on labour markets depending on the initial policy stance in the area considered) and policy complementarities; and, iii) sets of weights have to be assigned to individual policy categories in order to compute aggregate scores in broader policy fields.

28. Extensive testing shows that the ranking of countries in terms of overall reform intensity can be sensitive to the choice of weights attached to the scores in individual policy categories (see Brandt, Burniaux and Duval, 2005). 
Figure 4. Intensity and timing of recent labour market reforms in OECD countries (per cent of maximum possible score)

Panel A. Overall intensity of labour market reforms in individual OECD countries, 1994-2004

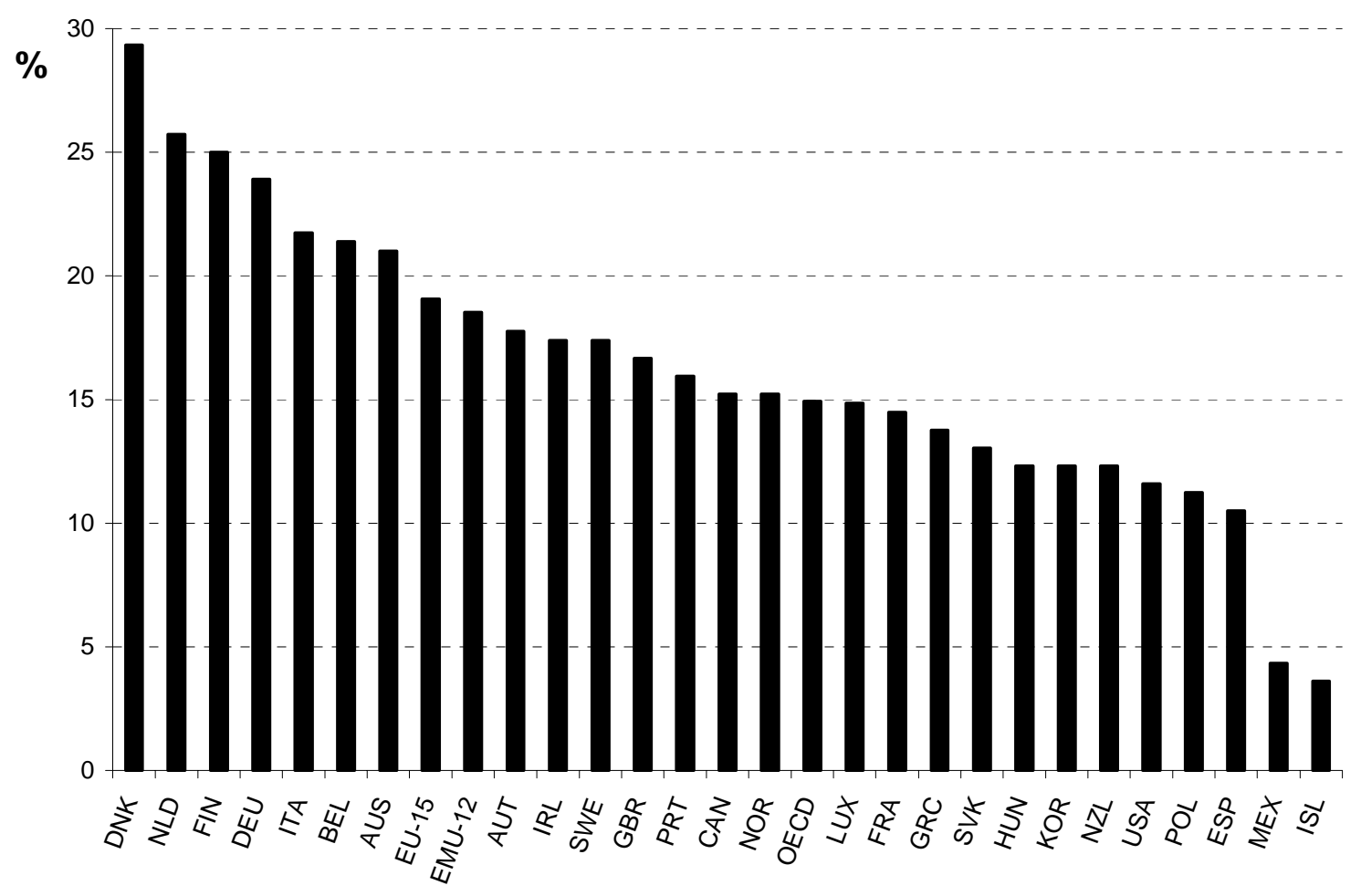

Source: Brandt, Burniaux and Duval (2005).

Panel B. Timing of recent labour market reforms in EU, EMU and OECD countries

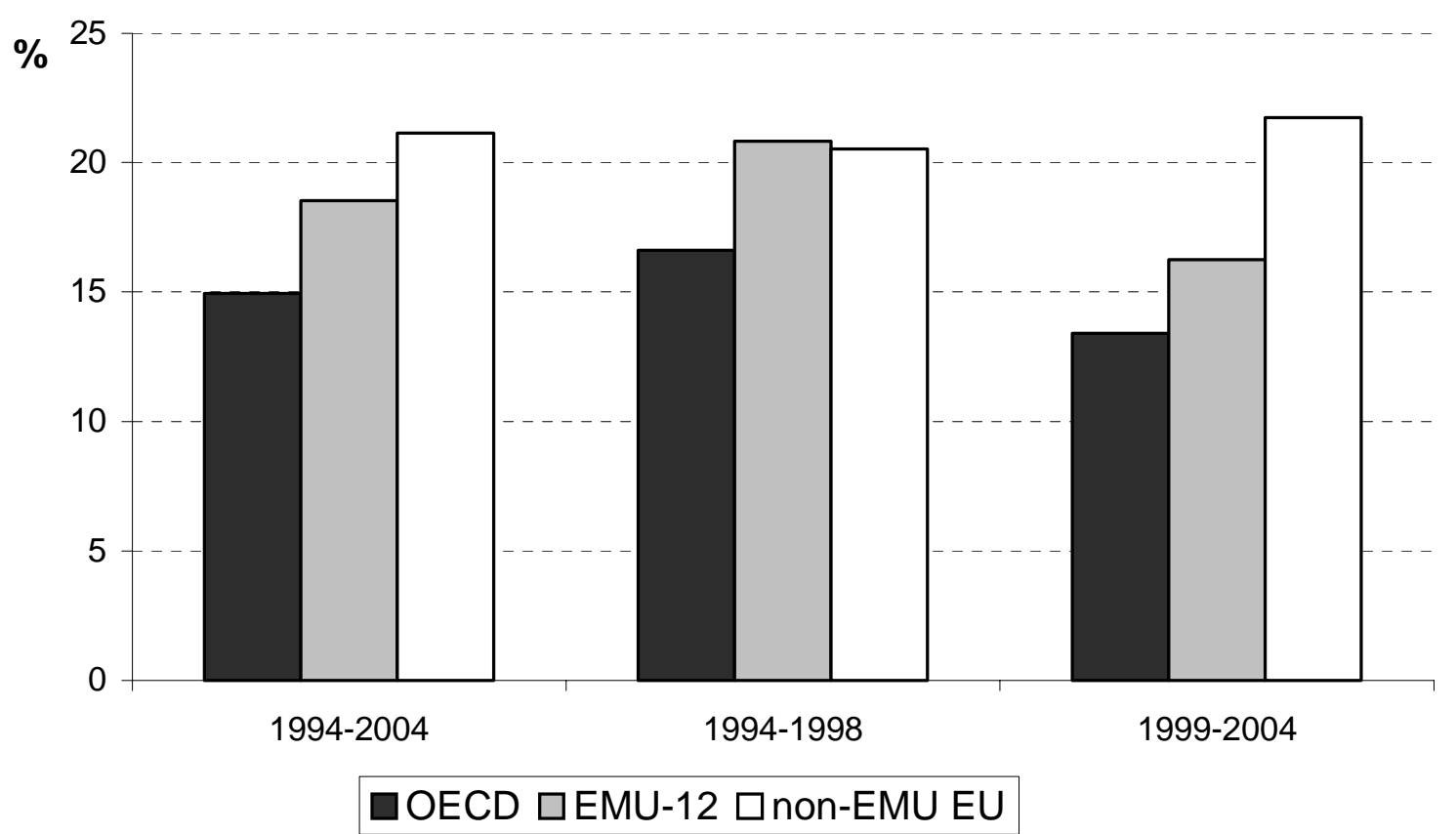

Source: Authors' adaptation based on Brandt, Burniaux and Duval (2005). 
Figure 5. Intensity of labour market reforms in OECD countries, 1994-2004 (per cent of maximum possible score)

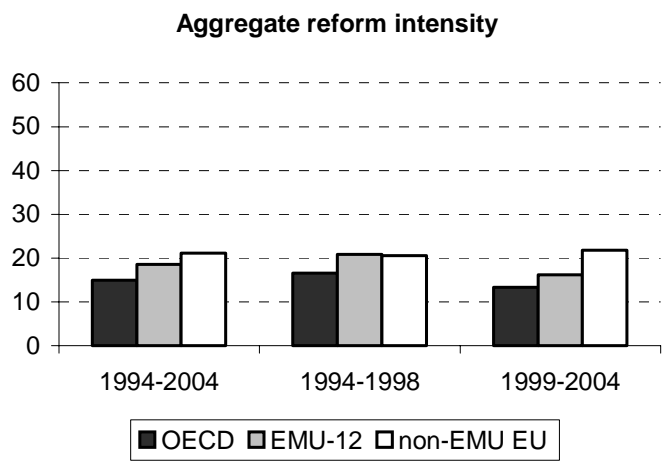

Taxes and social security contributions

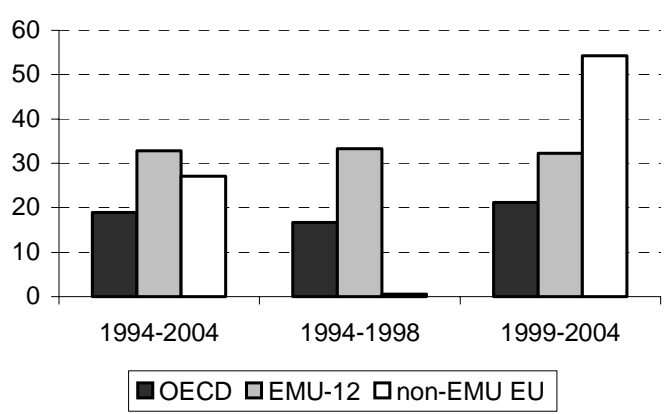

Unemployment benefit systems

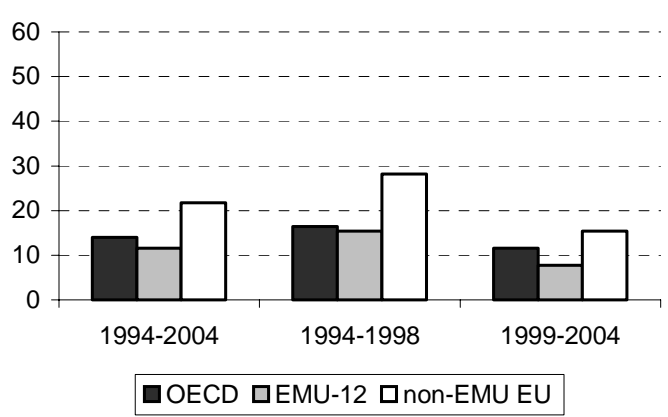

Working-time flexibility and part-time work

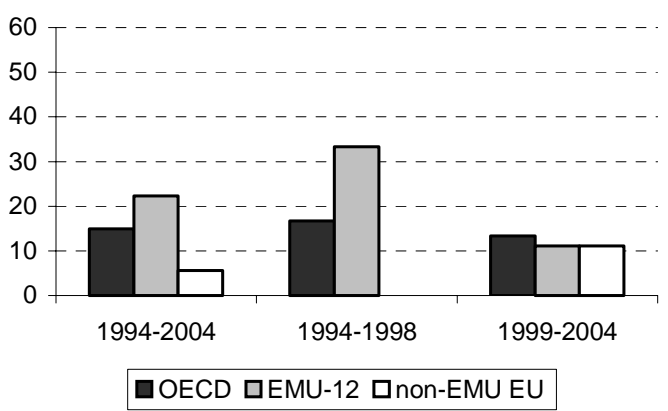

Active labour market policies

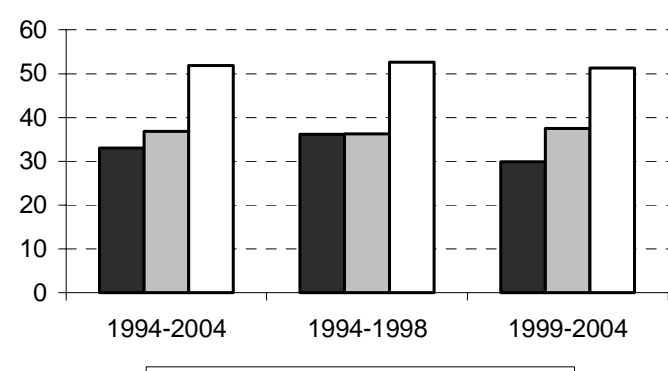

$\square$ OECD $\square$ EMU-12 $\square$ non-EMU EU

Employment protection

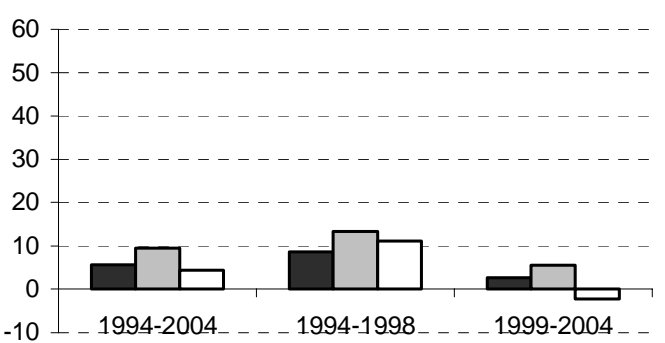

$\square$ OECD $\square$ EMU-12 $\square$ non-EMU EU

Retirement schemes

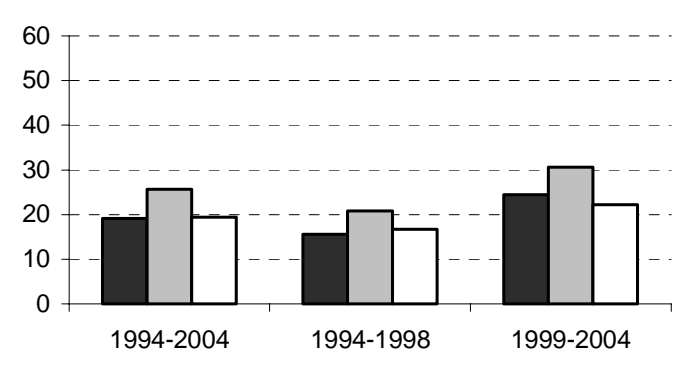

口OECD $\square E M U-12$ 口non-EMU EU

Wage formation and industrial relations

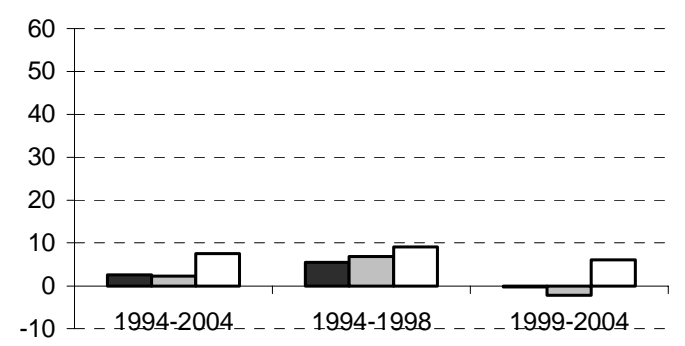

口OECD $\square E M U-12$ 口non-EMU EU

Source: Authors' adaptation based on Brandt, Burniaux and Duval (2005). 
$\mathrm{ECO} / \mathrm{WKP}(2005) 25$

Table 1. Aggregate reform intensity indicator, reform intensity indicators by area: ${ }^{1} 1994-2004$

\begin{tabular}{|c|c|c|c|c|c|c|c|c|c|}
\hline & $\begin{array}{r}\text { Summar } \\
\end{array}$ & $\begin{array}{l}n \text { intensity } \\
r^{2}\end{array}$ & & & Reform & ntensity indicator & by area ${ }^{2}$ & & \\
\hline & Score & Ranking & $\begin{array}{l}\text { Active labour } \\
\text { market policies }\end{array}$ & $\begin{array}{c}\text { Taxes and } \\
\text { social security } \\
\text { contributions }\end{array}$ & $\begin{array}{l}\text { Employment } \\
\text { protection } \\
\text { legislation }\end{array}$ & $\begin{array}{l}\text { Unemployment } \\
\text { benefit system }\end{array}$ & $\begin{array}{c}\text { Wage } \\
\text { formation and } \\
\text { industrial } \\
\text { relations }\end{array}$ & $\begin{array}{l}\text { Working-time } \\
\text { flexibility and } \\
\text { part-time work }\end{array}$ & $\begin{array}{c}\text { Early } \\
\text { retirement, } \\
\text { invalidity and } \\
\text { old-age } \\
\text { pension } \\
\text { schemes }\end{array}$ \\
\hline Australia & 21.0 & 7 & 54 & 25 & -7 & 19 & 27 & 0 & 17 \\
\hline Austria & 17.8 & 8 & 15 & 31 & 13 & 23 & 2 & 17 & 33 \\
\hline Belgium & 21.4 & 6 & 40 & 44 & 10 & 15 & 5 & 33 & 17 \\
\hline Canada & 15.2 & 13 & 38 & 13 & 0 & 23 & 0 & 17 & 17 \\
\hline Czech Republic & 6.2 & 28 & 17 & 0 & -3 & 12 & -5 & -17 & 33 \\
\hline Denmark & 29.3 & 1 & 56 & 13 & 10 & 42 & 27 & 17 & 25 \\
\hline Finland & 25.0 & 3 & 48 & 13 & 13 & 35 & 0 & 17 & 50 \\
\hline France & 14.5 & 16 & 42 & 31 & -7 & 0 & -5 & 33 & 42 \\
\hline Germany & 23.9 & 4 & 58 & 13 & 17 & 19 & 9 & 17 & 25 \\
\hline Greece & 13.8 & 17 & 42 & 13 & 7 & 12 & 5 & 17 & -8 \\
\hline Hungary & 12.3 & 19 & 31 & 25 & -7 & 19 & -9 & 0 & 33 \\
\hline Iceland & 3.6 & 30 & 19 & -38 & 0 & 19 & 0 & 0 & 8 \\
\hline Ireland & 17.4 & 9 & 46 & 88 & -10 & 15 & -14 & 0 & 0 \\
\hline Italy & 21.7 & 5 & 31 & 56 & 23 & -12 & 5 & 33 & 50 \\
\hline Japan & 8.7 & 25 & 23 & -13 & 13 & 4 & 0 & 33 & 8 \\
\hline Korea & 12.3 & 19 & 27 & 0 & 25 & 8 & 0 & 17 & 8 \\
\hline Luxembourg & 14.9 & 15 & 33 & 38 & 0 & 4 & -5 & 33 & 33 \\
\hline Mexico & 4.3 & 29 & 8 & 0 & 0 & 0 & 14 & 17 & 0 \\
\hline Netherlands & 25.7 & 2 & 56 & 25 & 13 & 12 & 14 & 33 & 42 \\
\hline New Zealand & 12.3 & 19 & 42 & 19 & -13 & 15 & -5 & 0 & 33 \\
\hline Norway & 15.2 & 13 & 46 & -19 & 10 & 27 & 0 & 17 & 8 \\
\hline Poland & 11.2 & 23 & 29 & 0 & -3 & 15 & 5 & 17 & 25 \\
\hline Portugal & 15.9 & 12 & 23 & 25 & 17 & 8 & 5 & 33 & 17 \\
\hline Slovak Republic & 13.0 & 18 & 12 & 25 & 14 & 19 & 0 & 17 & 8 \\
\hline Spain & 10.5 & 24 & 8 & 19 & 17 & 8 & 7 & 0 & 8 \\
\hline Sweden & 17.4 & 9 & 50 & 13 & 13 & 12 & 5 & 0 & 8 \\
\hline Switzerland & 8.7 & 25 & 23 & 6 & 0 & 15 & 0 & 17 & 0 \\
\hline Turkey & 6.5 & 27 & 4 & 0 & 13 & 8 & 0 & 33 & 8 \\
\hline United Kingdom & 16.7 & 11 & 50 & 56 & -10 & 12 & -9 & 0 & 25 \\
\hline United States & 11.6 & 22 & 19 & 50 & 0 & 12 & 0 & 0 & 0 \\
\hline OECD average & 14.9 & 15.3 & 33.0 & 19.0 & 5.6 & 14.0 & 2.6 & 15.0 & 19.2 \\
\hline EU-15 average & 19.1 & 9.5 & 39.9 & 31.7 & 8.4 & 13.6 & 3.3 & 18.9 & 24.4 \\
\hline EMU-12 average & 18.5 & 10.1 & 36.9 & 32.8 & 9.4 & 11.5 & 2.3 & 22.2 & 25.7 \\
\hline non-EMU EU & 21.1 & 7.0 & 51.9 & 27.1 & 4.4 & 21.8 & 7.6 & 5.6 & 19.4 \\
\hline EMU-bigs & 17.7 & 12.3 & 34.6 & 29.7 & 12.5 & 3.8 & 4.0 & 20.8 & 31.3 \\
\hline EMU-smalls & 19.0 & 9.0 & 38.0 & 34.4 & 7.9 & 15.4 & 1.4 & 22.9 & 22.9 \\
\hline
\end{tabular}

1: EMU-bigs: France, Germany, Italy and Spain.

EMU-smalls: Austria, Belgium, Finland, Greece, Ireland, Luxembourg, Netherlands and Portugal.

2: all reform intensity indicators are expressed as a percentage of the maximum possible socre, i.e. the score that would be obtained if all possible reforms were implemented. See main text for details.

Source: Brandt, Burniaux and Duval (2005)

Within each of these "difficult" areas, reform profiles also reflected hesitancy to take on insider interests. For example, most of the countries that reformed their EPL did so by easing regulations on fixed-term employment contracts while generally refraining from lowering EPL for permanent workers (Figure 6). Likewise, countries which reformed their unemployment benefit systems often tightened eligibility criteria, conditioned benefit receipt on participation in training and/or reduced associated work disincentives, but they typically did not move far in terms of reducing benefit replacement rates and duration or enforcing stricter work-availability criteria. Taking the two areas together, there is no obvious pattern differentiating euro-area countries from others in terms of either challenging or avoiding entrenched insider positions. 
Retirement systems are another area where resistance to reform is usually strong. Nonetheless, EMU countries (in particular Austria, Finland, France, Italy and the Netherlands) made more progress than OECD countries on average, possibly reflecting more urgent need for reform in this area within the context of ageing populations.

Figure 6. Intensity of labour market reforms in specific areas, 1994-2004 (per cent of maximum possible score)

\section{Employment protection}

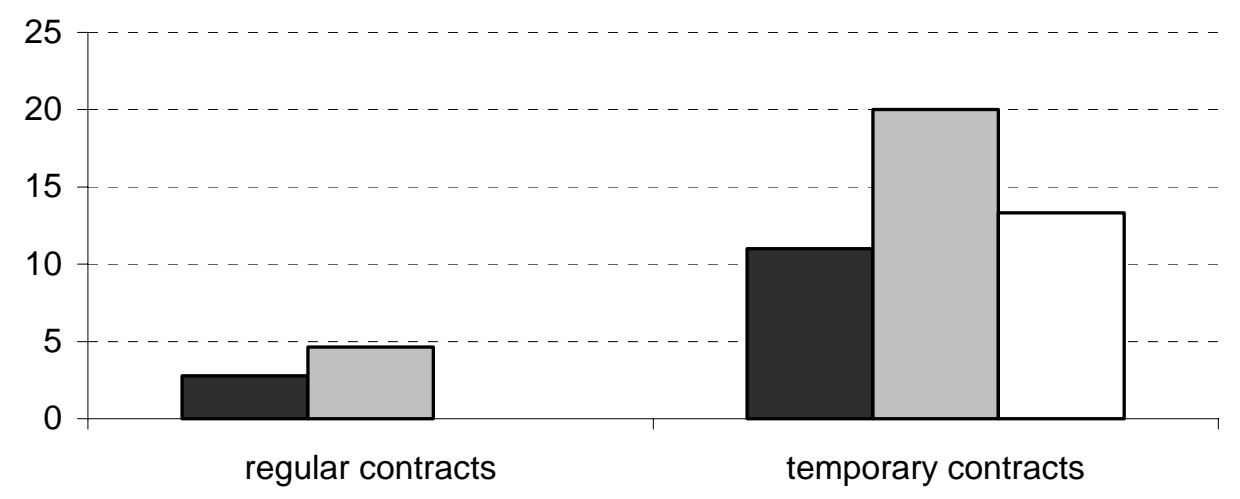

口OECD IEMU-12 पnon-EMU EU

\section{Unemployment benefits}

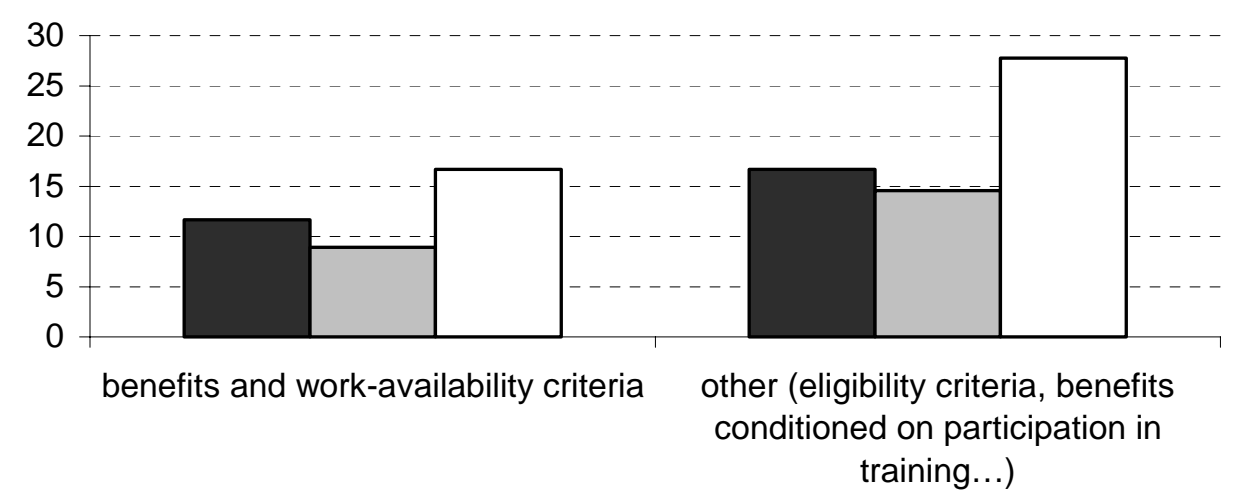

口OECD IEMU-12 पnon-EMU EU

Source: Authors' adaptation based on Brandt, Burniaux and Duval (2005). 


\section{Strength versus comprehensiveness of reforms}

Both theoretical and empirical evidence suggests that policy interactions can be important and that comprehensive reform packages tend to be more effective than "piece-meal" reforms in improving labour market outcomes. ${ }^{29}$ Figure 7 classifies OECD countries according to the breadth and depth of their reforms, in what may be regarded as a rough decomposition of the overall reform intensity indicator along the two dimensions. ${ }^{30}$ The breadth of reforms in each country is approximated here by the standard deviation of reform intensities across the seven areas mentioned previously: the lower the standard deviation, the more uniform reform intensities are and the broader the reform process is. Depth is defined as the magnitude of the reform effort in the main areas targeted by the country, measured as the average reform intensity across the three areas (among the seven covered in the aggregate reform intensity indicator) in which measured reform intensity is highest. ${ }^{31}$

Figure 7. Depth and breadth of labour market reforms

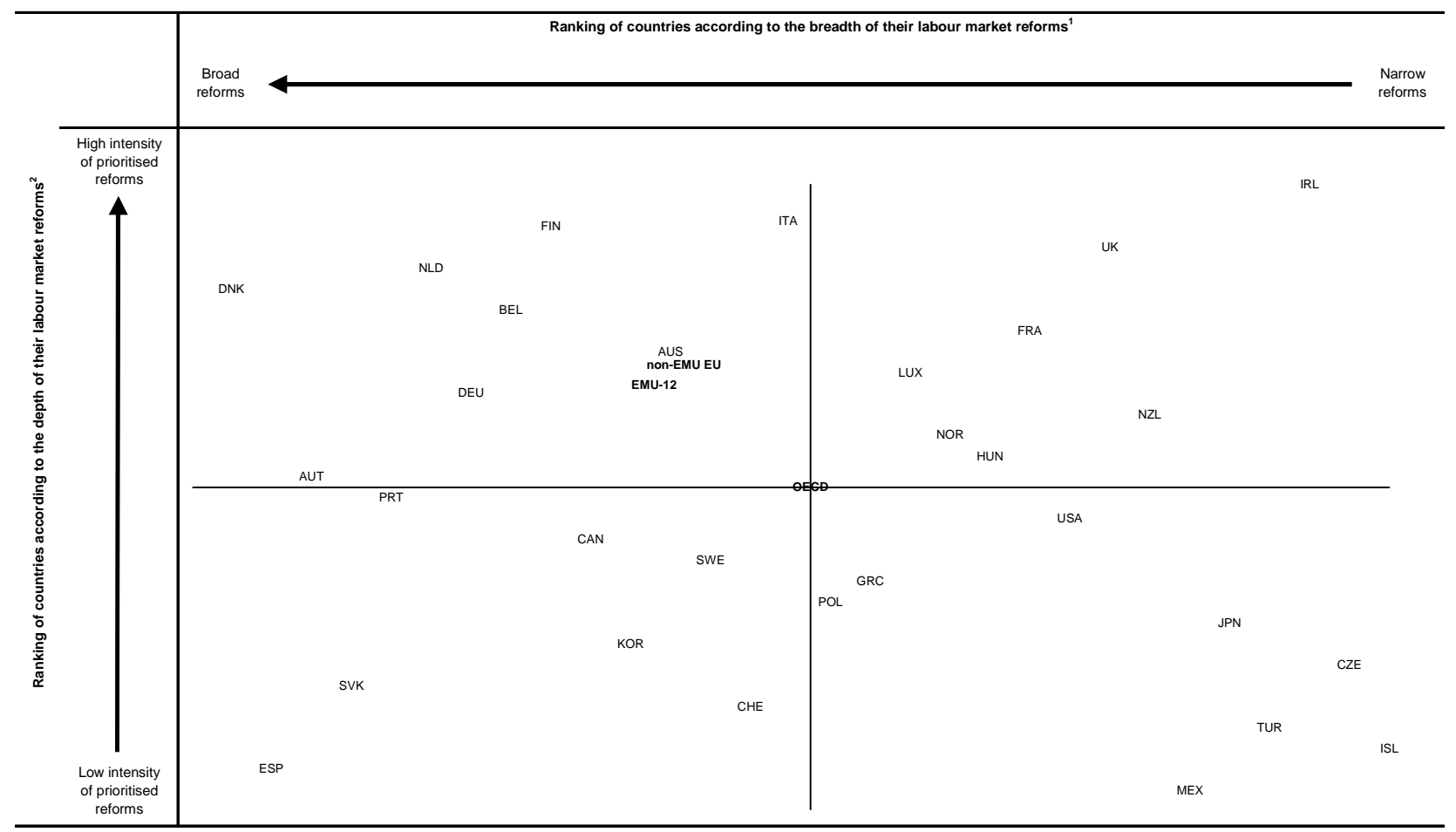

1. The breadth of reforms is measured as the normalised standard deviation of reform intensities across areas (the lower the standard deviation, the more uniform reform intensities are across areas). 2. The depth of labour market reforms is measured as the average reform intensity across the three areas in which the country's reform effort has been strongest.

Source: Brandt, Burniaux and Duval (2005).

29. For a theoretical framework stressing the importance of policy interactions, see Coe and Snower (1997). For empirical evidence, see for instance Belot and Van Ours (2000) or Elmeskov et al. (1998). As previously mentioned, complementarities may also exist as regards the political economy of reform.

30. For example, behind the broadly similar value of the overall indicator for Austria and the United Kingdom lie in fact very different compositions of reform, as Austria undertook moderate efforts spread over a wide range of areas while the United Kingdom carried out major reforms concentrated on two areas (labour taxes and ALMPs).

31. Considering the two - rather than three - highest reform intensities would alter only marginally the ranking of countries. 
On these criteria, Denmark, Finland and the Netherlands stand out for having made deep policy reforms in a wide range of areas since the mid-1990s, opening up for possible synergies. ${ }^{32}$ From a broader perspective, it is remarkable that the vast majority of countries located in the upper left quadrant of Figure 4.4 are EMU members (as noted above, Denmark is not a member of EMU but has its currency tied to the euro). At the same time, virtually no euro-area country - with the exception of Greece - is located in the lower right quadrant. This suggests that relative to the OECD average a number of euro-area countries have pursued both far-reaching and comprehensive reform strategies, while only few have confined themselves to either minor reforms or reforms covering only a small number of areas.

\section{Reform patterns with respect to initial conditions}

Euro-area countries' relatively favourable record in terms of breadth and depth of reform needs to be seen in light of their greater scope and need for reform. A noticeable feature of recent reform patterns within the euro area is their apparent lack of relationship with initial conditions. Based on rankings across all OECD countries of initial NAIRUs (in ascending order) and subsequent reform intensities (in descending order), those euro-area countries where reforms were arguably most needed have not necessarily acted more strongly, and vice versa (Figure 8, Panel A). Comparatively, and in line with the results of Van Poeck and Borghijs (2001) discussed above, structural policies in other OECD countries seem to have been more responsive to needs for reform (Figure 8, Panel B).

\section{Small versus large EMU countries}

For reasons already noted in Section 2, another relevant dimension of recent reform patterns in euro-area countries is country size. However, based on the reform indicators little systematic difference can be observed between reform intensities of small and large euro-area countries (Figure 9). Nevertheless, the two euro-area countries where overall reform intensity was the highest (Finland and the Netherlands) are small open economies, like the other top reforming country (Denmark). Not only have reforms in these countries been more intensive but they have also been more radical, ${ }^{33}$ with important pension reforms and substantial cuts in labour taxes and/or unemployment benefits.

\subsection{Product market reforms during the past decade}

An update of the OECD indicator of product market regulation (PMR) ${ }^{34}$ for non-manufacturing industries indicates that the reduction of regulatory impediments to product market competition between 1994 and 2004 was somewhat larger in euro-area than in other OECD countries, to some extent offsetting their stricter initial policy stance (Figure 10). There has been some convergence within the euro area, with greater deregulation occurring in the most regulated countries (Belgium, France, Greece, Ireland, Italy, Portugal and Spain). However, regulatory reform has proceeded roughly in line as between EMU and non-EMU EU countries, even though the latter started from a much more liberal position. ${ }^{35}$ These changes may reflect to a greater extent the EU integration process, including the single market, than EMU.

32. New Zealand would have fallen in the same category if the major reforms undertaken in the early 1990s, in particular within the context of the 1991 Employment Contracts Act, had been taken into account.

33. This feature is not fully captured by the indicators used in this section. Indeed, the score obtained by cumulating a series of minor reforms may be comparable to that reached by undertaking one single major reform, even if the latter in an economic sense exceeds the former.

34. See Conway, Janod and Nicoletti (2005).

35. Much of this move has been driven by the easing or elimination of coercive forms of regulation (such as command-and-control measures and price controls) and a reduction of controls on public or private business enterprise. Significant easing in all types of barriers to trade and investment has also been recorded. In contrast, progress in removing legal impediments to new entry in sectors sheltered from competition has been limited and the extent of privatisation has been modest. 
Figure 8. Initial conditions and intensity of labour market reforms

Panel A. Ranks of initial NAIRUs ${ }^{1}$ and ranks of reform intensities over 1994-2004: EMU countries

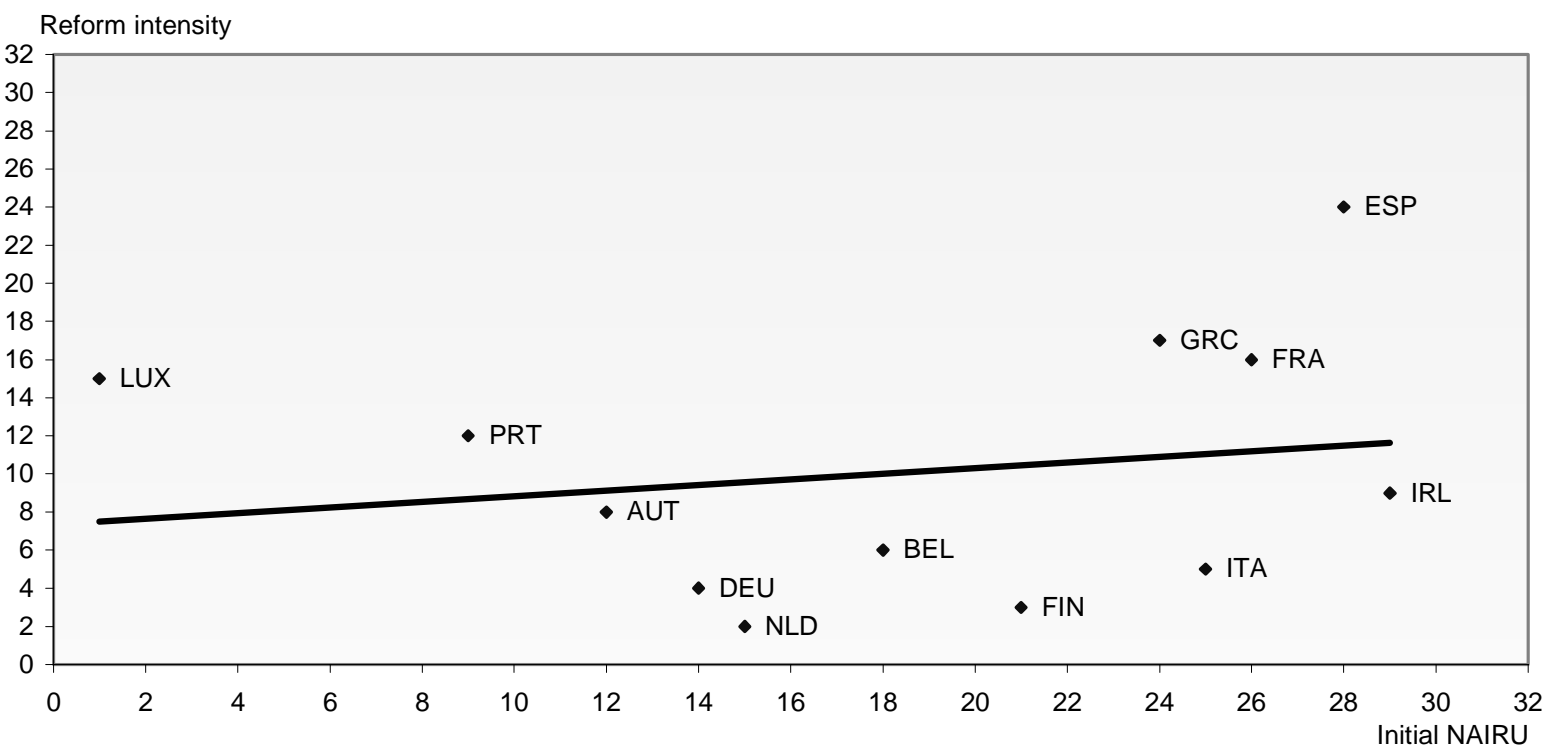

(Spearman's rank) correlation coefficient:

0.19

Panel B. Ranks of initial NAIRUs ${ }^{1}$ and ranks of reform intensities over 1994-2004: non-EMU, non-transition countries

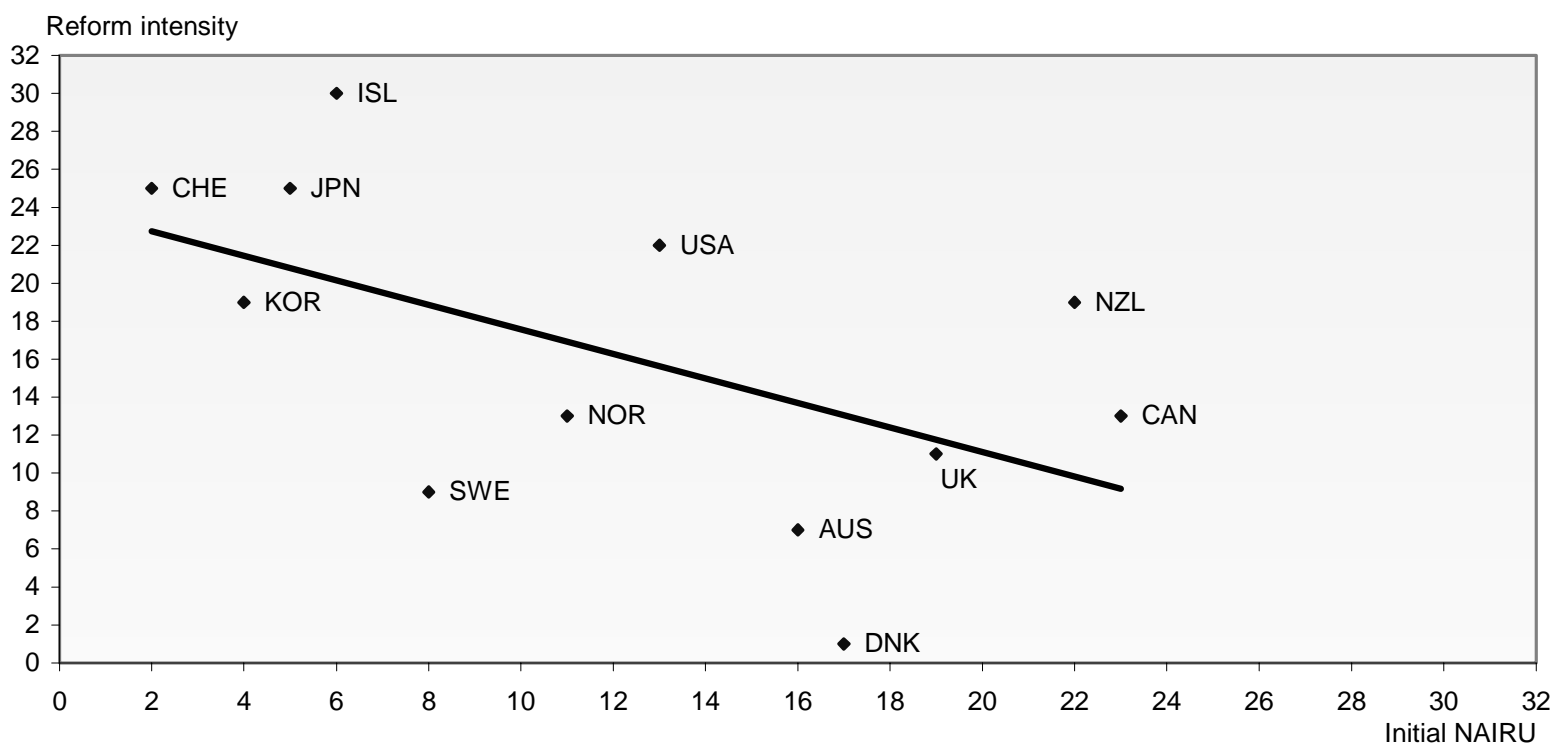

(Spearman's rank) correlation coefficient: $\quad-0.55$ *

1. Nairu estimates for 1993

* significant at $10 \%$ level; ** significant at $5 \%$ level.

Source: Authors' adaptation based on Brandt, Burniaux and Duval (2005). 
Figure 9. Intensity of labour market reforms in big and small EMU countries, ${ }^{\star}$ 1994-2004
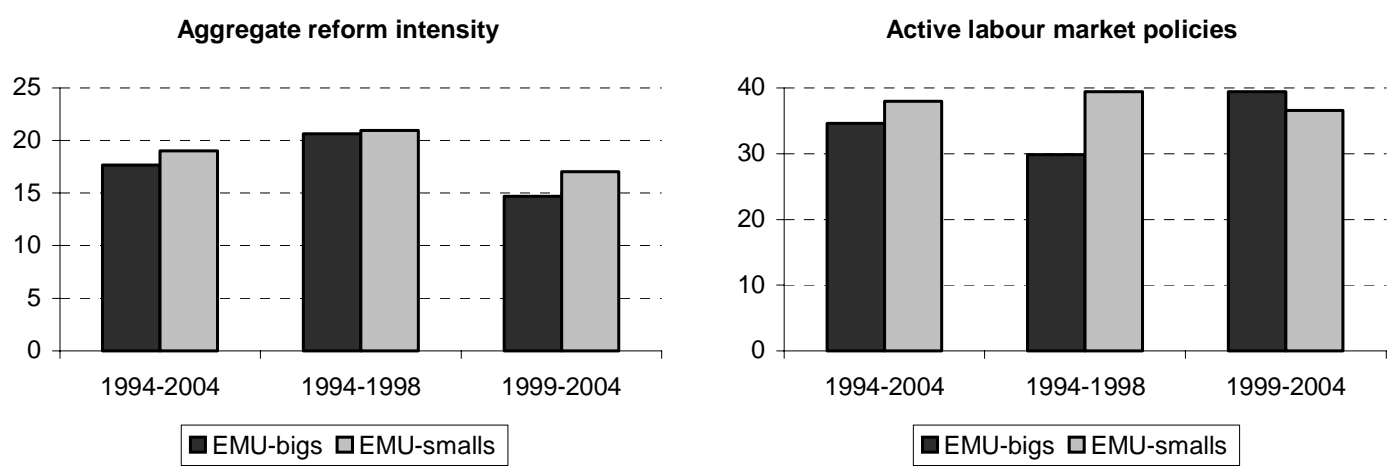

Taxes and social security contributions

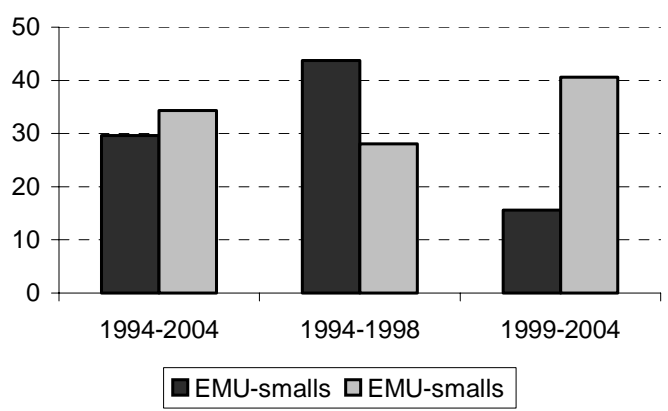

Employment protection

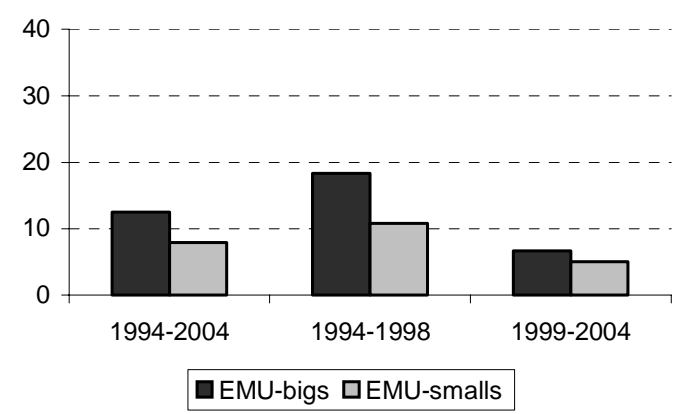

Unemployment benefit systems

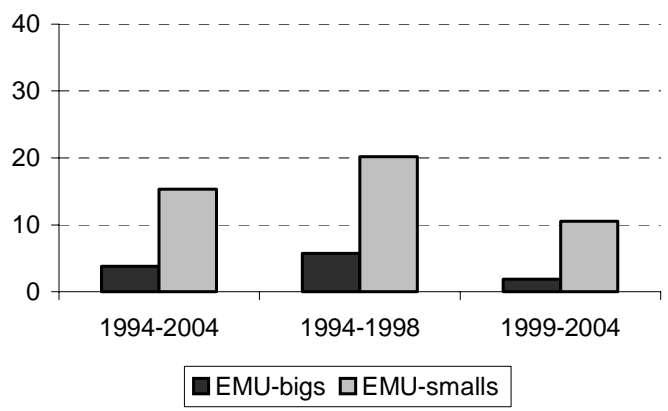

Retirement schemes

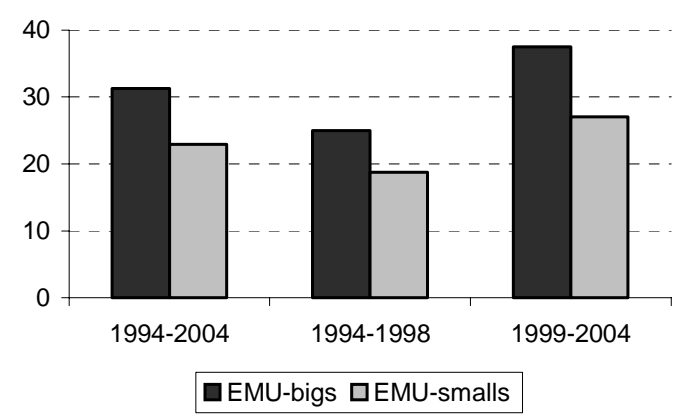

Working-time flexibility and part-time work

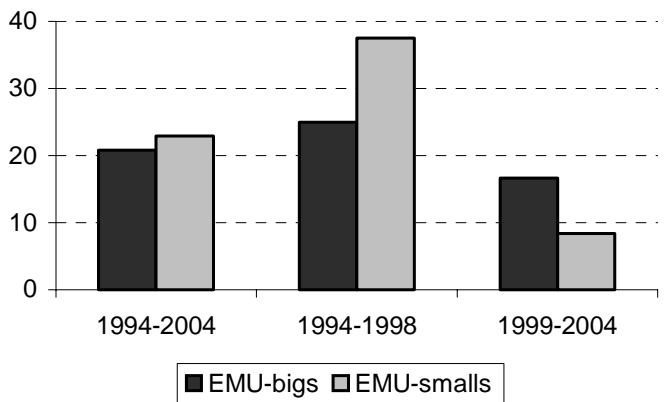

Wage formation and industrial relations

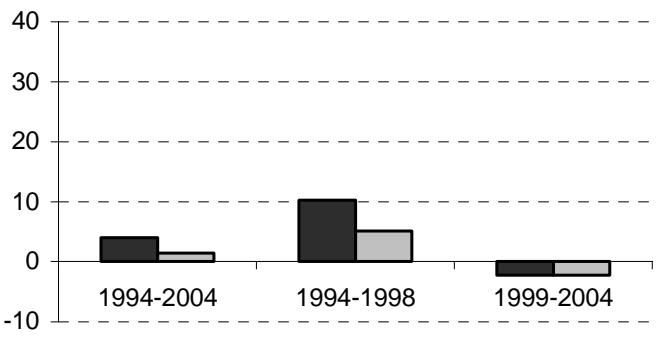

$\square$ EMU-bigs $\square$ EMU-smalls

*: Big countries: France, Germany, Italy and Spain. Small countries: other EMU countries.

Source: Authors' adaptation based on Brandt, Burniaux and Duval (2005). 


\section{Figure 10. Evolution of the OECD indicator of product market regulation in non-manufacturing industries, ${ }^{*}$ 1994-2003}

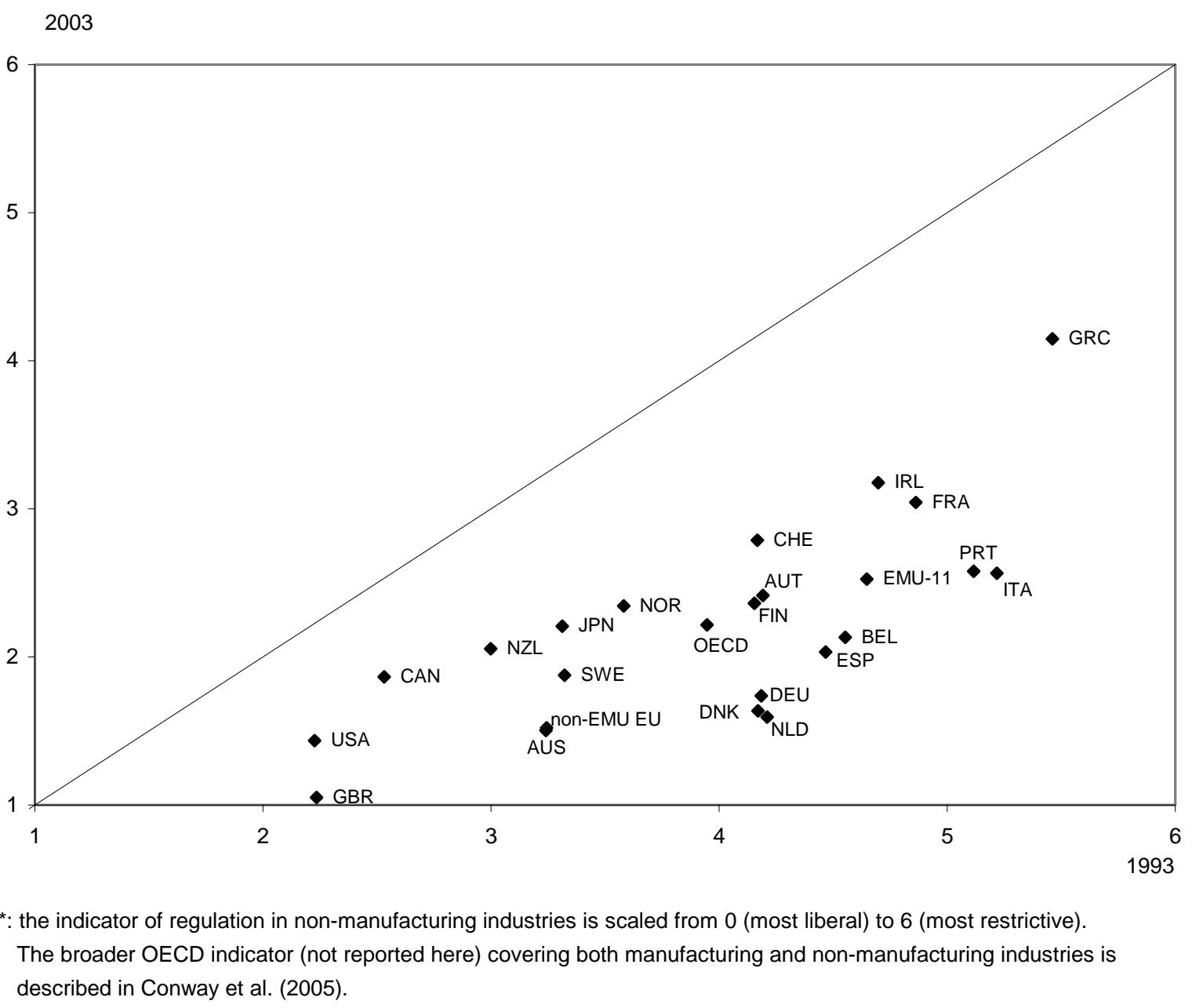

Finally, there is (highly) tentative evidence that product market deregulation could pave the way for subsequent labour market reforms, consistent with the view that reducing rents may progressively curb the support for labour market institutions aimed at capturing them. ${ }^{36}$ Several countries which have undertaken labour market reforms since 1999 had previously liberalised their product markets, as suggested by the cross-country correlation between the value of the aggregate labour-market reform intensity indicator over the sub-period 1998-2004 and the change in the OECD index of product market regulation for non-manufacturing industries over the previous sub-period 1993-98 (Figure 11). If such a political economy mechanism were to hold, EMU could ultimately facilitate the implementation of labour market reforms to the extent it boosts economic integration and product market competition.

36. See Blanchard and Giavazzi (2003) or Ebel and Haefke (2004). Product market reforms may also create better conditions to ease EPL via two other channels: $i$ ) they have a direct positive impact on overall employment, thereby reducing the incentives for incumbent workers to protect their jobs through strict EPL (Koeniger and Vindigni, 2003); and, ii) they increase the marginal employment gains that can be expected from less strict EPL (Kugler and Pica, 2004). 


\section{Figure 11. Changes in product market regulation over 1993-1998 and intensity of labour market reforms over 1999-2004*}

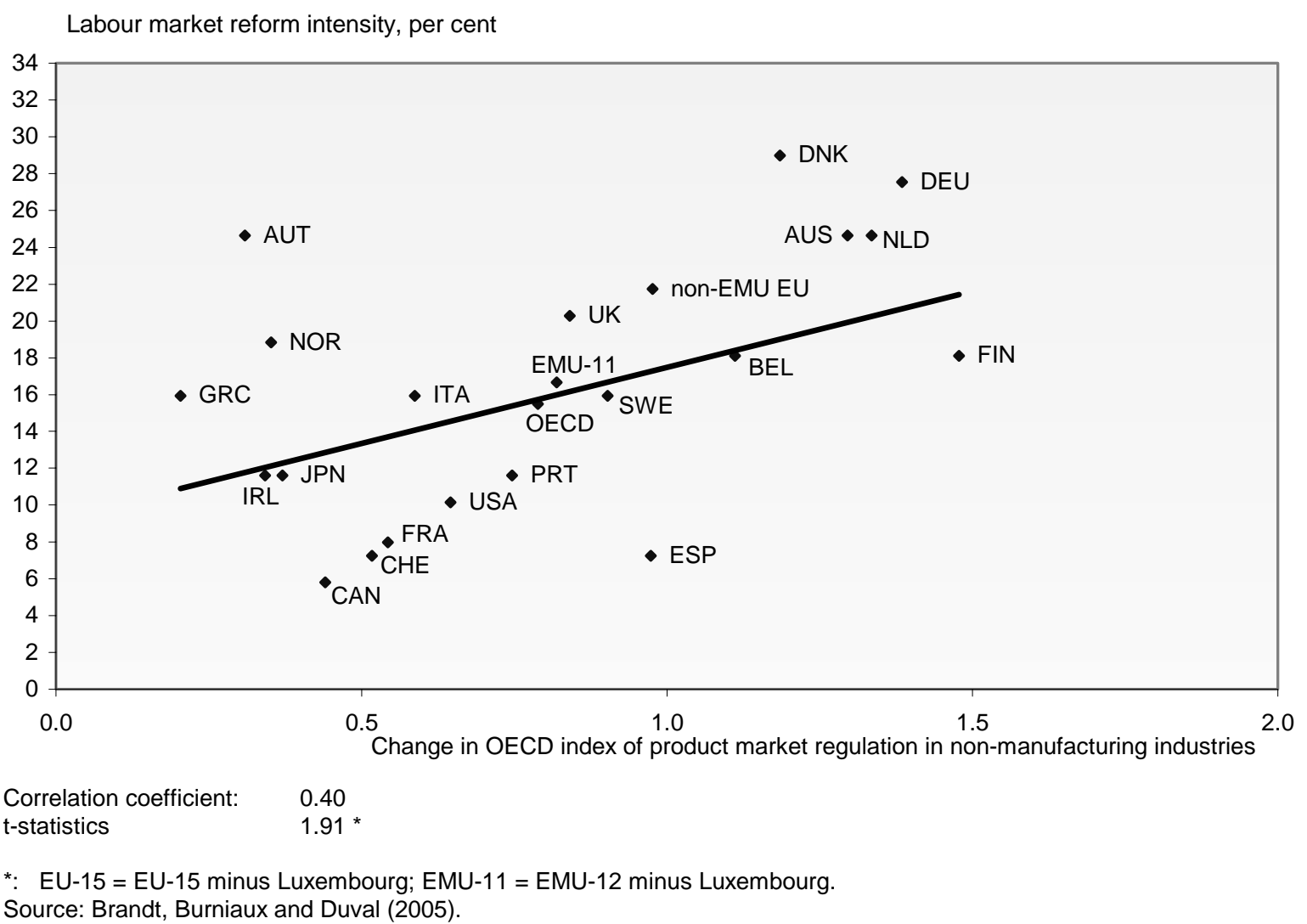

\subsection{Summing up the descriptive evidence}

A main conclusion is that euro-area countries typically have undertaken more comprehensive and far-reaching reforms than other OECD countries over the past decade. It is less clear whether EMU facilitated this process. Reform progress may have partly reflected the greater need for reform in the euro area, even though responsiveness to initial conditions appears to have been more pronounced in the rest of the OECD. Despite their poorer labour market performance and their stricter policy stance in a number of areas, EMU members have not been more active at reforming their labour and product markets than nonEMU EU countries. Furthermore, if anything, labour-market reform intensity has decelerated since the advent of EMU in 1999, while little or no slowdown has been observed in non-EMU EU and other OECD countries. However, this pattern of reform could possibly reflect expectations of EMU before its formal introduction. The observed correlation between prior product market reform and subsequent labour market reform could be a hopeful sign that if EMU strengthens product market competition then labour market reforms could become easier to undertake.

\section{Regression analysis}

For the reasons set out in Section 3 of this paper, assessing the impact of EMU on the pace and intensity of the reform process in Europe represents a challenge for more formal empirical research. In an effort to get around these difficulties, this section addresses a narrower but still closely related issue, namely whether the degree of autonomy of monetary policy is typically associated with a higher or lower 
propensity to carry out structural reforms. This approach makes it possible to exploit a wider cross-country/time-series dataset of structural reforms than would otherwise be possible. As a result, an econometric analysis of reform determinants can be undertaken which includes the autonomy of monetary policy as one of the explanatory variables.

An obvious drawback of the approach is that it fails to capture some of the unique characteristics of EMU compared with past fixed exchange-rate arrangements. Whether incentives to reform are stronger or weaker under EMU as compared with a fixed but adjustable peg is not clear-cut, however. On the one hand, EMU makes the "TINA" argument more compelling than other, less irreversible exchange-rate regimes. On the other hand, countries with fixed but adjustable exchange rates may have greater incentives to undertake reforms because of the possible exchange rate pressures and higher risk premia they may face if they fail to do so. Furthermore, the crowding-in mechanism described in Section 2.2, which suggests that monetary policy autonomy may help alleviate any short-run costs of reforms, may be more powerful under EMU than under past exchange rate arrangements. This is because under the latter countries still had the possibility to crowd-in resources via exchange rate devaluation, while this has become impossible under EMU.

Bearing the above caveat in mind, this section explores the driving factors of the structural policy reforms which have been carried out in OECD countries over the past two decades. Consistent with the rest of the paper, the analysis focuses on labour and - to a lesser extent - product markets. The modelling makes heavy use of OECD indicators of institutional arrangements and, in contrast with Section 4, restricts itself to major reforms as opposed to small ones. This emphasis facilitates the estimation of (non-linear) models of qualitative choice, which in theory should be more suitable than linear econometrics for the analysis of the decision to undertake a structural reform. ${ }^{37}$

The remainder of this section proceeds in three steps. Section 5.1 discusses briefly the expected effects of the explanatory variables featured in the regressions. Section 5.2 presents the annual dataset of major labour and product reforms assembled for 21 OECD countries over the period 1985-2003. ${ }^{38}$ Finally, Section 5.3 attempts to explain the probability to carry out major reforms by means of simple Probit estimates.

\subsection{Potential influences on the propensity to undertake reforms}

The analysis essentially seeks to determine whether having an autonomous monetary policy facilitates or impedes the reform process. Other potential influences which are controlled for in the econometric analysis are the following:

37. To the extent EMU and fixed exchange-rate regimes reduce the optimal size of reforms (Saint-Paul and Bentolila, 2000), the focus on major reforms in this empirical exercise may give a biased impression of the impact of monetary autonomy on the overall incidence of reform.

38. The countries covered are Australia, Austria, Belgium, Canada, Denmark, Finland, France, Germany, Greece, Ireland, Italy, Japan, Netherlands, New Zealand, Norway, Portugal, Spain, Sweden, Switzerland, United Kingdom, United States. 
- Macroeconomic situation:

Strict regulation of labour and - possibly - product markets is more likely to be perceived as counter-productive when labour market performance is weak. Over and above the possible impact of initial conditions on reform intensity, of which some simple bivariate evidence was found above for non-EMU countries, economic crises could play a specific role in fostering reforms. This is because a crisis situation may enable governments to overcome the "status quo" bias which in normal times can prevent welfare-enhancing reforms from being implemented. ${ }^{39}$

- Trade openness:

Due to "crowding-in" effects already discussed, it may be politically easier to carry out structural reforms in small open economies than in larger ones. Furthermore, high trade openness and the resulting high labour demand elasticity in small open economies may limit the ability of insiders to set wages above market-clearing levels, resulting in lower rents and thus lower public support for existing institutions (Saint-Paul, 2004).

- Current state of public finances:

Running substantial budgetary surpluses provides room for compensation of losers from structural reforms which, if used, can facilitate reforms. Furthermore, as noted by IMF (2004), the prevalence of a sound fiscal situation can make governments less reluctant to spend political capital - that otherwise would have had to be spent on unpopular fiscal adjustment measures - on structural reforms.

- Change in the situation of public finances:

A positive change in the fiscal balance could reduce the probability of reform, for the same reasons that the level of the fiscal balance can be expected to increase it: implementing reforms may require a temporary deterioration of the budgetary situation in order to compensate losers; efforts to improve the fiscal situation often entail political costs that may hamper the ability of governments to implement other types of unpopular measures such as structural reforms.

\section{- Political context:}

Insofar as structural reforms have short-term political and/or economic costs, governments may be inclined to postpone them until after general elections have been held. Therefore, reforms should occur more frequently right after general elections than just before them.

- Reforms undertaken in other fields:

Some of the specifications estimated below also control for the fact that implementing reforms in certain fields may pave the way for reforms in others. As argued above, reducing rents in one area may undermine the support for structural policies in other areas aimed at capturing such rent. Learning effects may also play a role, i.e. public support for structural reform may build up as the benefits of past reforms become more visible. Moreover, policy packages may be easier to implement than isolated reforms because they spread gains and losses more evenly across population groups and/or facilitate the compensation of losers.

39. See for instance Drazen (2000). 
ECO/WKP(2005)25

\section{2}

\section{Data construction}

The econometric analysis is based on an annual database of major structural reforms in 21 OECD countries over 1985-2003, constructed for the purpose of this paper. Sources and methodology are presented in detail in Annex 1. Compared with the descriptive evidence presented in Section 4, the focus here is as previously mentioned on major reforms only, and the coverage of policies is restricted to those areas that allow for quantitative description over an extended period. Hence, only five fields are considered for which available quantitative indicators of the policy stance make it possible to spot major reforms: unemployment benefit systems, labour taxes, employment protection legislation, product market regulation and retirement schemes.

The econometric regressions presented below are based on the assumption that explanatory variables have the same effect on the propensity to undertake major reform in any policy area. This assumption may not necessarily hold, at least as regards the impact of the degree of autonomy of monetary policy. Indeed, the thrust of the crowding-in argument put forward in Section 2 is that structural policies may be more easily reformed in a macroeconomic framework which enables monetary policy to react to short-run economic slack. This argument is less compelling for certain policy fields, e.g. labour tax cuts may actually stimulate aggregate demand more than aggregate supply in the short run. However, in practice, the strict definition of major labour tax reforms adopted in this section - a permanent 5 percentage points decline in the tax wedge (see below) - should ensure that such reforms have to be financed through cuts in expenditures that raise concerns about crowding in.

In each of the five policy fields, a major reform is assumed to be undertaken when the change in the corresponding quantitative policy indicator (e.g. the OECD summary measure of replacement rates in the case of unemployment benefit systems) exceeds two standard deviations of the indicator's sample average. ${ }^{40}$ This approach yields one reform indicator for each policy area, which takes the value 1 when observations - i.e. pairs (country, year) - correspond to a major policy reform and 0 otherwise. Crosscountry patterns of major reforms thereby identified appear to be roughly consistent with those presented in Section 4 for different types of reforms (both minor and major ones, covering a broader range of policy areas) over a shorter period (1994-2004 instead of 1985-2003) (Figure 12).

Many reforms do not occur in a single year but rather are spread over several consecutive years, in which case the indicator takes the value 1 throughout the whole period. In principle, this implies a risk that major, but gradual, reforms weigh too heavily in the data sample as compared with major, one-off reforms. As well, such gradual reforms might be implemented in years and under economic conditions that are significantly different from when they were decided, thereby possibly making it more difficult to identify the drivers of reform. In practice, however, protracted reform processes are rare in the policy areas and for the countries covered here.

The key explanatory variable considered in the regressions is the autonomy of national monetary policy. This variable is constructed as a dummy which takes value 1 when the country is not engaged in any kind of fixed exchange-rate arrangement (e.g. a peg, a monetary union or the former exchange-rate mechanism of the European Monetary System) and zero otherwise. Information on official exchange-rate

40. In the field of product market regulation, there has been a strong general trend toward liberalisation. To distinguish particular moves toward liberalisation from this general trend the indicator of product market regulation was initially de-trended. Without this procedure, which admittedly is somewhat ad hoc, product market reforms would have weighed very heavily in the data sample (see Annex 1). 
Figure 12. Share of countries where at least one major reform has been implemented over $1985-2003^{\star}$ (in per cent)
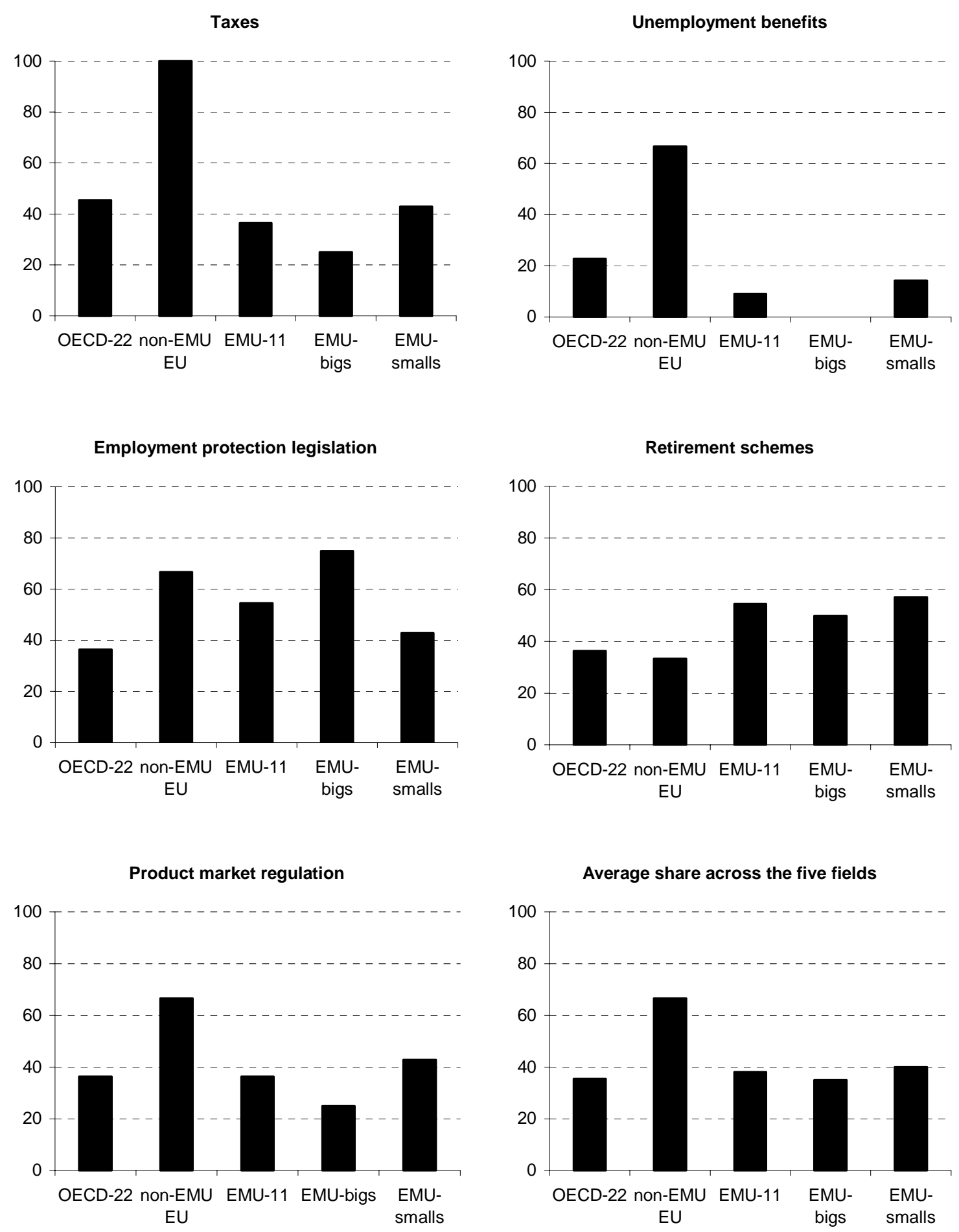

\section{*: EMU-11: EMU-12 minus Luxembourg.}

Big countries: France, Germany, Italy and Spain. Small countries: other EMU countries.

Source: Authors' calculations. 
arrangements is drawn from various issues of the annual IMF publication Exchange Arrangements and Exchange Restrictions. ${ }^{41}$ This definition obviously ignores that fixed exchange-rate commitments come in different shapes and forms. For example, the ERM contained countries that pursued a "hard" peg to the Deutsche Mark (e.g. Netherlands) as well as countries that underwent frequent depreciation. The lack of sophistication in the definition of monetary autonomy may create a bias in the estimations - probably in the direction of not finding any effects. ${ }^{42}$

Other variables are defined as follows:

- Initial labour market performance: unemployment rate of the 15-64 year-olds (Source: OECD, OECD Employment Outlook, June 2004).

- Economic crisis situation: dummy variable which takes value 1 when actual GDP is at least 4 percentage points below potential and 0 otherwise (Source: OECD, OECD Economic Outlook 76, December 2004).

- Small open economy: dummy variable which takes value 1 for the following countries: Austria, Belgium, Denmark, Finland, Greece, Ireland, Netherlands, New Zealand, Norway, Portugal, Sweden, Switzerland and 0 otherwise. These are the smallest countries in the sample in terms of GDP size. ${ }^{43}$

- Current state of public finances: general government fiscal balance as a share of GDP (Source: OECD, OECD Economic Outlook 76, December 2004).

- Change in the situation of public finances: first difference of the cyclically-adjusted general government fiscal balance as a share of GDP (Source: OECD, OECD Economic Outlook 76, December 2004). ${ }^{44}$

- Political context: general election year dummy which takes value 1 when a parliamentary or a presidential election takes place and 0 otherwise (Source: Worldbank, Database on Political Institutions).

41. Note that de jure exchange-rate regimes are not necessarily applied in practice (Levy Yeyati and Sturzenegger, 2001), even though this issue is generally far more relevant for developing countries than for the developed ones considered here. As a result, some adjustments were made. In particular, Austria was classified as having a fixed exchange rate regime over the full sample period even when it was not a formal member of the exchange rate mechanism of the European Monetary System. This is because this country maintained de facto a fixed exchange rate with the Deutsche Mark.

42. Another potential concern could be the asymmetry of the former European Monetary System. Indeed, it has been argued that German monetary policy acted as a "Stackelberg leader" under this system, while other central banks had to follow suit in order to maintain fixed exchange rates. In order to account for this possibility, the regressions presented in Tables 2 and 3 below were re-run assuming that Germany retained its monetary policy autonomy under the former EMS. The key findings were qualitatively unaffected.

43. Setting a cut-off point is not straightforward, considering for instance that the economic size of the smallest "large" country, Australia, exceeds only slightly that of the largest "small" country, the Netherlands (the gap between the two countries' GDP in PPPs was about 15\% in 2000). However, while Australia has the third lowest trade openness ratio in the OECD area (after the United States and Japan), the Netherlands has the third highest (after Belgium and Ireland). This suggests that Australia should be classified as a large country and the Netherlands as a small one.

44. The change in the cyclically-adjusted budget balance is conceptually closer to the stance of fiscal policy than the change in the actual budget balance. Hence, it should in principle be more representative of the political capital spent in consolidation of public finances. Nonetheless, the regressions below were also run using the change in the actual budget balance with no material difference in outcome. 


\section{ECO/WKP(2005)25}

\subsection{Probit regression results}

The five policy reform indicators can be used in two alternative ways. One option is to merge them so as to obtain an aggregate policy reform indicator which takes value 1 for those pairs (country, year) that correspond to major reform in at least one policy area and 0 otherwise. Alternatively, the individual policy reform indicators can be stacked up in order to expand dramatically the number of observations available for the econometric estimates. One problem with this option is that it rests implicitly on the assumption that structural reforms undertaken in a given pair (country, year) in different fields are independent from one another. However, this can be accounted for in the econometric estimates by controlling for the impact of reforms undertaken in other fields. Both pooled and stacked up datasets are used in the Probit regressions below.

\section{Estimates on pooled data}

Probit estimates on pooled data are presented in Table $2 .^{45}$ In order to mitigate potential endogeneity problems and to account for the fact that policy decisions may be reflected in the structural

Table 2.

Probit estimates of the determinants of structural reforms over 1985-2003: pooled data ${ }^{1}$

\begin{tabular}{|c|c|c|c|}
\hline & (1) & (2) & (3) \\
\hline Dependent variable: & Binary reform index & Binary reform index & Binary reform index \\
\hline Unemployment (-3) & $\begin{array}{c}0.02 \\
{[2.50]^{\star \star}}\end{array}$ & $\begin{array}{c}0.02 \\
{[2.65]^{* * *}}\end{array}$ & $\begin{array}{c}0.03 \\
{[2.91]^{\star * \star}}\end{array}$ \\
\hline Crisis $(-1)$ & $\begin{array}{c}0.41 \\
{[3.48]^{\star \star \star}}\end{array}$ & $\begin{array}{c}0.40 \\
{[3.40]^{\star \star *}}\end{array}$ & $\begin{array}{c}0.39 \\
{[3.26]^{\star * *}}\end{array}$ \\
\hline Small country & $\begin{array}{c}0.24 \\
{[4.11]^{\star \star \star}}\end{array}$ & $\begin{array}{c}0.26 \\
{[4.31]^{\star \star \star}}\end{array}$ & $\begin{array}{c}0.29 \\
{[4.34]^{\star \star \star}}\end{array}$ \\
\hline Fiscal surplus $(-1)$ & $\begin{array}{c}0.02 \\
{[2.87]^{\star \star \star}}\end{array}$ & $\begin{array}{c}0.02 \\
{[2.81]^{\star \star \star}}\end{array}$ & $\begin{array}{c}0.02 \\
{[2.94]^{\star \star \star}}\end{array}$ \\
\hline $\mathrm{D}$ (Cyclically-adjusted fiscal surplus $(-1))$ & $\begin{array}{l}-0.03 \\
{[1.18]}\end{array}$ & $\begin{array}{c}-0.03 \\
{[1.29]}\end{array}$ & $\begin{array}{l}-0.03 \\
{[1.37]}\end{array}$ \\
\hline General election year & $\begin{array}{c}0.00 \\
{[0.06]}\end{array}$ & & \\
\hline Independent monetary policy $(-1)$ & & $\begin{array}{c}0.07 \\
{[1.03]}\end{array}$ & $\begin{array}{c}0.07 \\
{[1.04]}\end{array}$ \\
\hline (Independent monetary policy $)^{\star}($ Large country) $(-1)$ & & & $\begin{array}{c}0.28 \\
{[2.27]^{* *}}\end{array}$ \\
\hline Pseudo-R2 & 0.10 & 0.11 & 0.12 \\
\hline $\begin{array}{l}\text { Proportion of } 1 \mathrm{~s} \text { in the estimation sample }(\mathrm{P} 1) \\
\text { Proportion of } 1 \mathrm{~s} \text { correctly predicted by the model } \\
\text { (prediction rule: predicted value }=1 \text { if } P(Y=1)>P 1)\end{array}$ & $\begin{array}{l}0.30 \\
0.68\end{array}$ & $\begin{array}{l}0.30 \\
0.68\end{array}$ & $\begin{array}{l}0.30 \\
0.86\end{array}$ \\
\hline Observations & 331 & 331 & 331 \\
\hline
\end{tabular}

1. Coefficients represent marginal probabilities.

Absolute value of robust z-statistics in parentheses, ${ }^{*}$ significant at $10 \%$ level, ${ }^{* *}$ significant at $5 \%,{ }^{\star * *}$ significant at $1 \%$.

45. Logit estimates yield (qualitatively) similar results. 
policy indicators with lags, most explanatory variables are lagged one (crisis, fiscal and independent monetary policy variables) or more (unemployment variable ${ }^{46}$ ) periods. ${ }^{47}$

Most control variables have the expected signs and are significant at standard confidence levels in the basic specification without monetary policy autonomy (equation 1). The two exceptions are the change in the fiscal balance and the election year dummy variable which are insignificant. ${ }^{48}$ The probability to carry out a structural reform in at least one of the five fields considered is estimated to be higher the poorer the recent macroeconomic conditions, the smaller the country size and the higher the level of the fiscal balance. Taking into account that the scale of the explanatory variables differs, the size of the estimated coefficients seems to imply that the largest impact on the propensity to reform would arise from the prevalence of an economic crisis and the size of the country.

When introduced into the basic specification, the independent monetary policy variable is insignificant (equation 2). However, consistent with the crowding-in argument made above, a significantly positive interaction ${ }^{49}$ is found between monetary policy autonomy and country size (equation 3 ) ${ }^{50}$ Taken at face value, the coefficient would imply that an autonomous monetary policy partly offsets the handicap that large countries in general seem to have in undertaking structural reform in labour or product markets. ${ }^{51}$

\section{Estimates on stacked data}

Estimates on stacked up data (Table 3) use the same specifications, except that they also control for the (lagged) effect of reforms made in other fields on the propensity to implement a reform in a given field. ${ }^{52}$ As already mentioned, this additional control variable aims to capture the fact that policy packages may create synergies across policy areas.

46. Unemployment being a highly auto-correlated variable, several alternative lags were statistically significant in the regressions. Here we selected the number of lags which maximized the t-stat of the unemployment rate variable ( 3 periods).

47. This approach does not deal with any links between, on the one hand, the variable capturing monetary autonomy and, on the other hand, the macroeconomic control variables. However, given the nature of the monetary autonomy variable and the long estimation period any such problem is likely to be minor.

48. Lags and leads of the election year dummy were also found to be insignificant in the same specification.

49. Following a standard procedure, interactions between variables $\mathrm{X}_{\mathrm{it}}$ and $\mathrm{Y}_{\mathrm{it}}$-here, the autonomous monetary policy and country size dummies, respectively- are specified as $\left(X_{i t}-\bar{X}_{. .}\right)\left(Y_{i t}-\bar{Y}_{\text {.. }}\right)$, where

$\bar{X}_{. .}$and $\bar{Y}$.. are the sample averages of $\mathrm{X}_{\mathrm{it}}$ and $\mathrm{Y}_{\mathrm{it}}$, respectively. With this specification, the coefficients of $\mathrm{X}_{\mathrm{it}}$ and $\mathrm{Y}_{\mathrm{it}}$ have a straightforward interpretation, i.e. they measure the direct effects of these variables for an average, hypothetical country. This is because the interaction term is equal to zero at the sample average.

50. In to explore whether EMU affected the propensity to reform over and above any impact it may have had via the loss of the monetary policy tool, a "euro area membership" dummy - taking value 1 for EMU countries starting from 1999 and zero otherwise - was tried in some specifications. It always turned out to be insignificant and had no effect on the size and significance of the other coefficients.

51. The specification and the coefficient of the interaction variable imply that an autonomous monetary policy increases the probability of a major reform by around .17 in large countries compared with small ones.

52. For each of the five policy fields considered, this variable takes values comprised between 0 and 4 depending on the number of reforms carried out in the other four fields. 
Table 3.

Probit estimates of the determinants of structural reforms over 1985-2003: stacked up data ${ }^{1}$

\begin{tabular}{|c|c|c|c|c|}
\hline & (1) & (2) & (3) & (4) \\
\hline Dependent variable: & $\begin{array}{l}\text { Binary reform } \\
\text { index }\end{array}$ & $\begin{array}{l}\text { Binary reform } \\
\text { index }\end{array}$ & $\begin{array}{l}\text { Binary reform } \\
\text { index }\end{array}$ & $\begin{array}{l}\text { Binary reform } \\
\text { index excluding } \\
\text { EPL reforms }\end{array}$ \\
\hline Other reforms $(-1)$ & $\begin{array}{c}0.05 \\
{[5.54]^{\star \star \star}}\end{array}$ & $\begin{array}{c}0.05 \\
{[5.30]^{\star \star \star}}\end{array}$ & $\begin{array}{c}0.05 \\
{[5.47]^{\star \star \star}}\end{array}$ & $\begin{array}{c}0.07 \\
{[5.94]^{\star \star \star}}\end{array}$ \\
\hline Unemployment (-3) & $\begin{array}{c}0.01 \\
{[2.80]^{\star \star \star}}\end{array}$ & $\begin{array}{c}0.01 \\
{[2.86]^{\star * \star}}\end{array}$ & $\begin{array}{c}0.01 \\
{[2.84]^{\star \star \star}}\end{array}$ & $\begin{array}{c}0.01 \\
{[3.27]^{\star \star \star}}\end{array}$ \\
\hline Crisis $(-1)$ & $\begin{array}{c}0.12 \\
{[3.40]^{\star * *}}\end{array}$ & $\begin{array}{c}0.11 \\
{[3.23]^{* * *}}\end{array}$ & $\begin{array}{c}0.11 \\
{[3.23]^{\star * *}}\end{array}$ & $\begin{array}{c}0.15 \\
{[3.64]^{\star * *}}\end{array}$ \\
\hline Small country & $\begin{array}{c}0.07 \\
{[4.28]^{\star \star \star}}\end{array}$ & $\begin{array}{c}0.08 \\
{[4.38]^{\star \star \star}}\end{array}$ & $\begin{array}{c}0.08 \\
{[4.33]^{\star \star \star}}\end{array}$ & $\begin{array}{c}0.11 \\
{[4.73]^{\star \star \star}}\end{array}$ \\
\hline Fiscal surplus $(-1)$ & $\begin{array}{c}0.01 \\
{[3.26]^{\star * *}}\end{array}$ & $\begin{array}{c}0.01 \\
{[3.29]^{\star * *}}\end{array}$ & $\begin{array}{c}0.01 \\
{[3.28]^{* * *}}\end{array}$ & $\begin{array}{c}0.01 \\
{[4.72]^{\star * *}}\end{array}$ \\
\hline $\mathrm{D}($ Cyclically-adjusted fiscal surplus $(-1))$ & $\begin{array}{c}0.00 \\
{[0.31]}\end{array}$ & $\begin{array}{c}0.00 \\
{[0.45]}\end{array}$ & $\begin{array}{c}0.00 \\
{[0.45]}\end{array}$ & $\begin{array}{c}0.00 \\
{[0.51]}\end{array}$ \\
\hline General election year & $\begin{array}{l}-0.01 \\
{[0.36]}\end{array}$ & & & \\
\hline Independent monetary policy (-1) & & $\begin{array}{c}0.01 \\
{[0.84]}\end{array}$ & $\begin{array}{c}0.02 \\
{[0.88]}\end{array}$ & $\begin{array}{c}0.05 \\
{[2.45]^{\star *}}\end{array}$ \\
\hline (Independent monetary policy $)^{\star}($ Large country) $(-1)$ & & & $\begin{array}{c}0.01 \\
{[0.38]}\end{array}$ & $\begin{array}{c}0.05 \\
{[1.10]}\end{array}$ \\
\hline Pseudo-R2 & 0.09 & 0.09 & 0.09 & 0.13 \\
\hline $\begin{array}{l}\text { Proportion of } 1 \mathrm{~s} \text { in the estimation sample }(\mathrm{P} 1) \\
\text { Proportion of } 1 \mathrm{~s} \text { correctly predicted by the model } \\
\text { (prediction rule: predicted value }=1 \text { if } P(Y=1)>P 1)\end{array}$ & $\begin{array}{l}0.13 \\
0.66\end{array}$ & $\begin{array}{l}0.13 \\
0.68\end{array}$ & $\begin{array}{l}0.13 \\
0.68\end{array}$ & $\begin{array}{l}0.15 \\
0.68\end{array}$ \\
\hline Observations & 1655 & 1655 & 1655 & 1324 \\
\hline
\end{tabular}

1. Coefficients represent marginal probabilities.

Absolute value of robust z-statistics in parentheses, * significant at $10 \%$ level, ${ }^{* *}$ significant at $5 \%,{ }^{* \star *}$ significant at $1 \%$.

The control variables are again statistically significant at conventional levels, with the exception of the lagged change in the fiscal balance and the election year dummy (equation 1 ) ${ }^{53}$ Reforms made in other fields are also found to be highly significant, supporting the view that major reforms are typically "bunched" into packages and/or that policy changes in certain areas can pave the way for reforms in others. In line with estimates on pooled data, the independent monetary policy variable is insignificant (equation 2), but in contrast to the previous estimations, this remains the case where it is interacted with the large country dummy (equation 3 ).

The insignificance of monetary policy autonomy appears to reflect at least partly the absence of the previously observed linkage in the case of EPL reform. Most EPL reforms included in the sample reflect a relaxation of rules governing temporary contracts rather than a deregulation of regular contracts. ${ }^{54}$

53. As previously, however, neither lags nor leads of the election year dummy are found to be significant.

54. The only experiences of substantial relaxation of rules governing regular contracts are Portugal (19891991) and Spain (1994), starting from a very high degree of stringency in both cases. By contrast, there 
Such partial EPL reforms may be politically easier to implement and therefore less likely to be driven by some of the determinants featured in the equation. Put differently, it is debatable whether such reforms really qualify as "major". When excluding EPL reforms from the sample, an independent monetary policy is found to increase the probability of a reform (in one of the four remaining policy fields), though no significant interaction is found with country size (equation 4$) .55,56$

\section{Implications}

Summing up, the issue of how EMU affects the political economy of structural reform needs to be put in perspective. For well-known reasons, structural reform is usually an uphill battle and in that greater scheme of things, the effect of EMU is likely to be only a marginal influence. Furthermore, as discussed above, the theoretical arguments as to the effect of EMU on structural reform point in opposite directions. Hence, the actual influence of EMU becomes an empirical question. With EMU in existence for only a few years it is, however, difficult to draw firm conclusions as to its impact from available data.

The descriptive evidence on recent reform patterns presented in this paper suggests that euro area countries typically have undertaken more comprehensive and far-reaching reforms than other OECD countries over the past decade. However, there is little if any evidence that EMU facilitated this process. Different reform intensities between EMU and non-EMU countries need to be seen in the light of greater need for reform in the former. As well, there appears to have been a slowdown in the reform process in EMU countries after the formal advent of the euro - though this could reflect the prior race to qualify for EMU. Furthermore, EMU countries - with the exception of a few small ones - have shown no particular ability to carry out needed reforms in areas where political resistance is normally strong (with the exception of retirement schemes where impending fiscal pressures are particularly large in EMU countries). Finally, progress in reform across EMU countries is not obviously linked to reform needs - in contrast to what is observed among other OECD countries.

Nonetheless, the problem with descriptive evidence is that it is difficult to identify with any confidence the drivers behind the observed patterns of structural reform. Unfortunately, the brief experience with EMU makes it difficult to undertake econometric analysis aimed at identifying the marginal impact of EMU on the pace of structural reform. In consequence, the current paper has cast the net more widely and explored the impact of monetary policy autonomy more generally on structural reform across most OECD countries. The argument for this approach is that most structural policies are set by individual euro-area countries and that these to some extent resemble countries pursuing a fixed exchange-rate regime. It has to be recognised, however, that participation in EMU is different from operating a fixed but adjustable peg. Whether the greater commitment associated with EMU should imply more or less reform is not clear-cut, however.

The upshot of the analysis is that many of the "usual suspects" indeed do seem to determine the pace of structural reform, such as going through an economic crisis and more broadly experiencing high unemployment. There is also evidence that a sound fiscal balance may help, possibly because it provides governments with sufficient political capital - which otherwise would have to be spent on fiscal adjustment measures - and gives room for the compensation of losers. Furthermore, implementing reforms in a given

have been numerous cases of deregulation of temporary contracts: Belgium (1997), Denmark (1995), Germany (1997), Italy (since 1997), The Netherlands (1999) and Sweden (1993).

55. Dropping the insignificant interaction term from the last column of Table 3 would leave other results unchanged.

56. In principle, the use of stacked up data makes it possible to undertake the analysis of the determinants of structural reforms at the level of each policy area. However, the scarcity of reforms in each field considered individually suggests - and estimates confirmed - that this is likely to bring few robust findings. 
policy field is found to pave the way for and/or to coincide with reforms in other areas. As concerns the role of the monetary policy regime, the absence of monetary policy autonomy seems to be associated with lower structural reform activity - at least in large, more closed economies but possibly more widely. Independently of monetary policy regime, small economies seemed to undertake more reform over the period considered which runs from the mid-1980s to 2003.

The results concerning the influence of monetary autonomy and country size can be rationalised within a framework where structural reform is expected to create slack resources in economies. In small open economies such slack is more quickly taken up through changes in net trade and incentives to undertake structural reform are therefore stronger. In larger, more closed economies, by contrast, net trade is less powerful as a mechanism for taking up slack. Hence, such economies are more reliant on accommodation through monetary policy when they undertake structural reform, and when exchange-rate arrangements exclude such accommodation they undertake less reform. This, however, does not exclude that scope for monetary accommodation could enhance structural reform also in smaller countries.

Obviously these simple findings should not be exaggerated. However, if additional testing suggests that they are robust it would point to a potentially problematic aspect of EMU. In particular, an effect of EMU in the direction of weakening the incentives for structural reform would be a cause for concern. The presence of any such tendency would naturally prompt the question whether a more co-ordinated approach to structural reform could enable greater monetary accommodation and thereby increase the incentives for undertaking reform. Unfortunately, however, this may be more complicated than it sounds:

- Countries have widely different starting points as regards structural policy settings and therefore different needs in terms of reform.

- As well, even similar structural reforms may well have different supply and demand-side effects across countries - in part because reform will interact with pre-existing institutions and structural policy settings - which would make the overall effect on area-wide inflation and demand-pressure hard to predict and to factor into monetary policy.

Hence, it is not obvious that stronger and more binding co-ordination of structural policy is the way forward. Indeed, it may also be seen as conflicting with the subsidiarity principle. Against this background, there may be little alternative to soldiering on with the so-called open method of co-ordination - essentially based on jaw-boning and peer pressure - and trying to make that as effective as possible.

At the same time, some of the descriptive evidence presented in the paper suggests that structural reforms in product markets, which may be politically easier to undertake, can pave the way for labour market reforms. This evidence is supported by signs of positive feed-back between reforms in different areas emerging from the regression analysis. The results concerning fiscal policy also suggest that progress towards consolidation may eventually provide a more auspicious background for structural reform. If results such as these prove robust to further testing, they may provide clues as to how to strengthen the overall reform process. It would be sad if structural reform were eventually driven by a factor that empirically is strongly correlated with reform: crisis. 
ECO/WKP(2005)25

\section{REFERENCES}

Alesina, A., E. Glaeser, B. Sacerdote (2005), "Work and Leisure in the U.S. and Europe: Why so Different?", NBER Working Paper Series, No. 11278.

Angeloni, I., A.K. Kashyap, B. Mojon and D. Terlizzese (2003), "The Output Composition Puzzle: a Difference in the Monetary Transmission Mechanism in the Euro Area and the US", NBER Working Paper Series, No. 9985.

Bean, C. (1998), “The Interaction of Aggregate Demand Policies and Labor Market Reform”, Swedish Economic Policy Review, Vol. 5/2.

Belot, M. and J. van Ours (2000), "Does the Recent Success of Some OECD Countries in Lowering their Unemployment Rates Lie in the Clever Design of their Labour Market Reforms?", CEPR Discussion Papers No. 2492, June.

Bertola, G. and T. Boeri (2001), "EMU Labour Markets Two Years On: Microeconomic Tensions and Institutional Evolution", paper presented at the Workshop "The Functioning of EMU: Challenges of the Early Years" organized by the Directorate General for Economic and Financial Affairs, European Commission, Brussels, 21-22 March 2001, April 27 2001 version.

Blanchard, O. and F. Giavazzi (2003), "Macroeconomic Effects of Regulations and Deregulation in Goods and Labour Markets", Quarterly Journal of Economics, Vol. 118.

Bourles, Renaud and Gilbert Cette (2005), "Une comparaison des niveaux de productivité structurels des grands pays industrialisés", mimeo.

Brandt, N., J-M. Burniaux and R. Duval (2005), "Assessing the OECD Jobs Strategy: Past Developments and Reforms", OECD Economics Department Working Paper No. 429, OECD, Paris.

Calmfors, Lars (2001a), "Unemployment, Labour-Market Reform and Monetary Union", Journal of Labor Economics, Vol. 19, No. 2.

Calmfors, Lars (2001b), "Wages and Wage-bargaining Institutions in the EMU - A Survey of the Issues", IIES Working Papers, No. 690.

Catte, P., N. Girouard, R. Price and C. André (2004), "Housing Markets, Wealth and the Business Cycle", OECD Economics Department Working Papers, No. 394.

Coe, D. and D. Snower (1997), "Policy Complementarities: The Case for Fundamental Labour Market Reform", IMF Staff Papers Vol. 44.

Conway, P., V. Janod and G. Nicoletti (2005) "Product Market Regulation in OECD Countries: 1998 to 2003", Economics Department Working Paper No. 419, OECD, Paris. 
Drazen, A. (2000), Political Economy in Macroeconomics, Princeton, New Jersey, Princeton University Press.

de Grauwe, Paul and Francesco Paolo Mongelli (2004), paper presented at the Conference on Monetary Union in Europe: Historical Perspectives and Prospects for the Future, University of Copenhagen, 10 December.

Duval, R. (2004), "Retirement Behaviour in OECD Countries: Impact of Old-age Pension Schemes and Other Social Transfer Programmes", OECD Economic Studies, No. 37.

Ebell, M., C. Haefke (2003), "Product Market Deregulation and Labour Market Outcomes", Swiss National Bank Working Papers, 02.08.

Elmeskov, J., J.P. Martin and S. Scarpetta (1998), "Key Lessons for Labour Market Reforms: Evidence from OECD Countries’ Experience”, Swedish Economic Policy Review, Vol. 5/2.

Haffner, R.C.G., S. Nickell, G. Nicoletti, S. Scarpetta and G. Zoega (2000), "European Integration, Liberalisation and Labour Market Performance", Report for the Fondazione Rodolfo DeBenedetti.

IMF (2004), "Fostering Structural Reforms in Industrial Countries", Chapter III in World Economic Outlook. Advancing Structural Reforms, April, International Monetary Fund, Washington D.C.

Jaumotte, F. (2004), "Labour Force Participation of Women: Empirical Evidence on the Role of Policy and Other Determinants in OECD Countries", OECD Economic Studies, No. 37.

Kennedy, Mike and Torsten Sløk (2005), "Structural Policy Reforms and External Imbalances”, OECD Economics Department Working Papers, No. 415.

Krueger, A.B. and J.S. Pischke (1997), "Observations and Conjectures on the US Employment Miracle", NBER Working Paper No. 6146.

Kugler, A. and G. Pica (2004), "Effects of Employment Protection and Product Market Regulation on the Italian Labor Market", paper presented at the CEPR/ECB Workshop, June.

Landers, R.M., J.B. Rebitzer and L.J. Taylor (1996), "Rat Race Relax: Adverse Selection in the Determination of Work Hours in Law Firms", American Economic Review, Vol. 86/3.

Levy, Yeyati E. and F. Sturzenegger (2001), "Classifying Exchange Rate Regimes: Deeds vs. Words", European Economic Review, Vol. 49(6), August, p. 1603-1635.

Nicoletti Giuseppe, Steve Golub, Dana Hajkova, Daniel Mirza and Kwang-Yeol Yoo (2003), "Policies and International Integration: Influences on Trade and Foreign Direct Investment", OECD Economics Department Working Papers, No. 359.

OECD (1997), Implementing the OECD Jobs Strategy: Member Countries' Experience, OECD, Paris.

OECD (1999), Implementing the OECD Jobs Strategy: Assessing Performance and Policy, OECD, Paris.

OECD (2004a), OECD Economic Surveys - Euro Area, OECD, Paris.

OECD (2004b), "Saving Behaviour and the Effectiveness of Fiscal Policy", OECD Economic Outlook, No. 76, OECD, Paris. 
OECD (2005a), Society at a Glance - OECD Social Indicators, OECD, Paris.

OECD (2005b), Economic Policy Reforms. Going for Growth, OECD, Paris.

Olson, Mancur (1965), The Logic of Collective Action, Harvard University Press, Cambridge, Massachusetts.

Orszag, M. and D.J. Snower (1998), “Anatomy of Policy Complementarities”, Swedish Economic Policy Review, Vol. 5/2.

van Poeck, André and Alain Borghijs (2001), EMU and Labour Market Reform: Needs, Incentives and Realisations, Blackwell Publishers, Oxford.

Posen, Adam S. (2004), "The Euro, Stabilization Policy, and the Stability and Growth Pact or Can Rubinomics Work in the Eurozone", paper presented at the Conference on The Euro at Five: Ready for a Global Role, 26 February.

Prescott, E.C. (2004), "Why Do Americans Work So Much More Than Europeans?", Federal Reserve Bank of Minneapolis Quarterly Review, Vol. 28/1.

Saint-Paul, Gilles (2004), "Why are European Countries Diverging in their Unemployment Experience", IZA Discussion Paper No. 1066, March.

Saint-Paul, Gilles and Samuel Bentolila (2000), “Will EMU Increase Eurosclerosis?”, International Macroeconomics and Labour Economics, CEPR Discussion Paper No. 2423, April. 


\section{ANNEX 1: CONSTRUCTION OF THE POLICY REFORM DATABASE}

In order to construct an annual database of structural reforms, it would seem natural to collect information for each country regarding when major reforms were voted. However, not only is such an approach difficult - especially for reforms that were carried out prior the first publication of the $O E C D$ Jobs Study in 1994 - but more importantly it suffers from two important limitations: while our focus should be clearly on major reforms, there is no straightforward criterion a priori to distinguish them from small ones; certain reforms start small before getting big over the years and therefore can not be associated with any specific year. One example is the slow but quasi continuous decline in tax wedges in Denmark between the late 1980s and the mid-1990s or in Finland since the mid-1990s.

Here these two limitations are dealt with as follows. First, in order to identify major reforms, we rely exclusively on a posteriori criteria: a major reform in a given policy area (e.g. product markets) is one that is accompanied by a "substantial" change in a corresponding quantitative policy indicator (e.g. the OECD indicator of product market regulation). This approach was already taken to construct the reform intensity indexes presented in Section 4, but only to a limited extent since more qualitative information was also taken into account. Second, if the "substantial" change in the policy indicator does not occur in a particular year but rather is spread over a longer period, then all the corresponding years are assumed to have been reform years. This is implicitly consistent with the view that a country engaged in a reform process has the possibility to opt out every year, so that the continuation of a reform process can by itself be regarded as a "reform".

We restrict our analysis to five key policy areas for which straightforward quantitative indicators can be used to assess the magnitude of policy reforms. These are unemployment benefit systems, labour taxes, employment protection legislation, product market regulation and retirement schemes, for which the quantitative indicators used are, respectively: the OECD summary measure of benefit replacement rates (an average of replacement rates across various earnings levels, family situations and durations of unemployment); an average of OECD measures of the wedge between labour cost and take-home pay across two situations (a single worker and a couple with a dependent spouse and two children, at average earnings levels in both cases); the OECD summary index of employment protection legislation; the OECD summary index of product market regulation in seven non-manufacturing industries; an average of OECD measures of implicit tax rates on continued work - which sum up deviations from actuarial neutrality - in old-age pension systems and early retirement schemes across thee situations (at ages 55 and 60 in early retirement schemes, and at age 60 in old-age pension schemes, for a single worker with average earnings in all three cases). ${ }^{57}$ All these indicators are available for 21 OECD countries over the period 1985-2003.

The threshold beyond which a change in the policy indicator is assumed to signal a major policy reform is set as follows. For each of the five policy areas mentioned above, the standard deviation of the annual change in the corresponding quantitative indicator is calculated over all available observations (typically 399, corresponding to 21 countries over the period 1985-2003). A major reform is then assumed

57. The main sources for these indicators are respectively: OECD, Benefits and Wages, various issues ; OECD, Taxing Wages, various issues; OECD (2004a), Employment Outlook, Paris; Nicoletti, G. and S. Scarpetta (2003), "Regulation, productivity and growth", Economic Policy, No. 36; Conway et al. (2005), "Product market regulation in OECD countries: 1998 to 2003", OECD Economics Department Working Paper No. 419, OECD, Paris; Duval, R. (2003), "Retirement Behaviour in OECD Countries: Impact of Old-age Pension Schemes and Other Social Transfer Programs" OECD Economic Studies No. 37, 2003/2, OECD, Paris. 
to have been undertaken when the overall change in the policy indicator exceeds two standard deviations. In practice, this corresponds respectively to: a decline in the benefit replacement rate indicator larger than 6.5 percentage points; a decline in the tax wedge measure larger than 5 percentage points; a decline in the summary index of employment protection legislation larger than 0.5 units (the average value of the index over the sample considered is 2.1); a decline in the de-trended indicator of product market regulation larger than 0.6 units (the average value of the de-trended index over the sample considered is 5 ) ${ }^{58}$ a decline in the average implicit tax rate on continued work larger than 6.5 percentage points.

We obtain one reform indicator for each policy area, which takes value 1 when observations - i.e. pairs (country, year) - correspond to a major policy reform and 0 otherwise. Two alternative ways can then be envisaged to exploit these five reform variables:

- One option is to merge them so as to obtain an aggregate policy reform indicator which takes value 1 for those pairs (country, year) that correspond to at least one major policy reform and 0 otherwise.

- Alternatively, they can be stacked up in order to expand dramatically the amount of information available for the econometric estimates. One problem with this option is that it rests implicitly on the assumption that structural reforms undertaken in a given pair (country, year) in different fields are independent from one another. However, this can be accounted for in the econometric estimates by controlling for the impact of reforms undertaken in other fields.

Therefore, both pooled and stacked up datasets are used alternatively in the Probit regressions presented in Section 5 of the main text.

58. The rationale for de-trending the product market regulation indicator is to control for the general decline observed across the OECD area over the sample period. In the absence of such a control, our methodology would identify a disproportionately large number of reforms compared with other policy fields. Instead, here only declines in product market regulation that have gone substantially beyond the general trend towards deregulation are considered as major policy reforms. 
ECO/WKP(2005)25

\section{WORKING PAPERS}

The full series of Economics Department Working Papers can be consulted at www.oecd.org/eco/Working_Papers/

437. Product market competition and economic performance in New Zealand (July 2005) Annabelle Mourougane and Michael Wise

436. Getting the most out of public sector decentralisation in Spain (July 2005) Isabelle Joumard and Claude Giorno

435. Sources of inflation persistence in the euro area (July 2005) Boris Cournède, Alexandra Janovskaia, Paul van den Noord

434. Measuring Cyclically-Adjusted Budget Balances for OECD Countries (July 2005) Nathalie Girouard and Christophe André

433. Product Market Competition and Economic Performance in the United Kingdom (June 2005) Maria Maher and Michael Wise

432. The Benefits of Liberalising Product Markets and Reducing Barriers to International Trade and Investment: the Case of the United States and the European Union (June 2005)

431. Boosting Growth through Greater Competition in Denmark (May 2005) Martin Jørgensen

430. Fifteen Years of Economic Reform in Russia: What Has Been Achieved: What Remains to be Done? (May 2005) Rudiger Ahrend and William Tompson

429. Assessing the OECD Job Strategy: Past Developments and Reforms (May 2005) Nicola Brandt, Jean-Marc Burniaux and Romain Duval

428. Ageing, Welfare Services and Municipalities in Finland (May 2005) Jens Lundsgaard

427. The Impact of Structural Policies on Trade-Related Adjustment and the Shift to Services (April 2005) Per Mathis Kongsrud and Isabelle Wanner

426. Product Market Competition and Economic Performance in Iceland (April 2005) Thomas Laubach and Michael Wise

425. Enhancing Brazil's Regulatory Framework for Network Industries: The Case of Electricity, Oil and Gas, and Water and Sanitation (April 2005) Edmar Almeida and Nanno Mulder

424. Education Attainment in Brazil: The Experience of FUNDEF (April 2005) Luiz de Mello and Mombert Hoppe

423. Estimating a Fiscal Reaction Function: The Case of Debt Sustainability in Brazil (April 2005) Luiz de Mello

422. Product Market Competition and Economic Performance in the Netherlands (April 2005) Maria Maher and Michael Wise

421. Product Market Competition and Economic Performance in Canada (April 2005) Maria Maher and Jay Shaffer 
420. The Impact of Ageing on Demand, Factor Markets and Growth (April 2005) Joaquim Oliveira Martins, Frédéric Gonand, Pablo Antolin, Christine de la Maisonneuve and Kwang-Yeol Yoo.

419. Product Market Regulation in OECD Countries: 1998 to 2003

(February 2005) Paul Conway, Véronique Janod and Giuseppe Nicoletti

418. Reforming Turkey's Public Expenditure Management

(February 2005) Rauf Gönenç, Willi Leibfritz and Erdal Yilmaz

417. Fiscal Gimmickry in Europe: One-Off Measures and Creative Accounting (February 2005) Vincent Koen and Paul van den Noord

416. Getting the Most out of Public Sector Decentralisation in Japan (January 2005) Isabelle Joumard and Tadashi Yokoyama

415. Structural Policy Reforms and External Imbalances (January 2005) Mike Kennedy and Torsten Sløk

414. The Jobs Challenge in Poland: Policies to Raise Employment (January 2005) Andrew Burns and Przemyslaw Kowalski

413. Product Market Competition and Economic Performance in Finland (December 2004) Jens Høj and Michael Wise

412. Oil Price Developments: Drivers, Economic Consequences and Policy Responses (December 2004) Anne-Marie Brook, Robert Price, Douglas Sutherland, Niels Westerlund and Christophe André

411. Wealth Effects on Money Demand in EMU: Econometric Evidence (November 2004) Laurence Boone, Fanny Mikol and Paul van den Noord

410. Banking Reform in Russia: Problems and Prospects (November 2004) William Tompson

409. Public Expenditure in France (November 2004) Andrew Burns and Alessandro Goglio

409 La gestion des dépenses publiques en France (Novembre 2004) Andrew Burns et Alessandro Goglio

408. Russian Industrial Restructuring: Trends in Productivity, Competitiveness and Comparative Advantage (October 2004) Rudiger Ahrend

407. Improving the Capacity to Innovate in Germany (October 2004) Andrés Fuentes, Eckhard Wurzel and Margaret Morgan

406. Tax Treatment of Private Pension Savings in OECD Countries and the Net Tax Cost per Unit of Contribution to Tax-Favoured Schemes (October 2004) Kwang-Yeol Yoo and Alain de Serres

405. The Reform of the Health Care System in Portugal (October 2004) Stéphanie Guichard

404. Accounting for Russia's Post-Crisis Growth (October 2004) Rudiger Ahrend 